\title{
STUDENT SERVICES FOR ADULT UNDERGRADUATE STUDENTS AT VIRGINIA'S FOUR-YEAR COLLEGES
}

\author{
A Dissertation \\ Presented to \\ The Faculty of the Curry School of Education \\ University of Virginia
}

In Partial Fulfillment

of the Requirements for the Degree

Doctor of Philosophy

by

Kathryn Danielle Soule

B.A., University of Kentucky, 1987

M.Ed., University of Maine, 1992

May 1998 


\section{Abstract}

The purpose of this study was to investigate the student services offered to adult students at the four-year undergraduate colleges and universities in Virginia. Three particular aspects of the services were investigated: 1) discover the student services currently available to adult undergraduate students at the four-year institutions, 2) determine which of these services were successful or unsuccessful in attracting adult students, and 3) ascertain if there were additional student services needed to accommodate their students. The adult students were defined as being at least 25 years old and enrolled in full- or part-time undergraduate course work in any program at Virginia's 15 public and 27 private four-year undergraduate colleges.

A survey instrument was developed and administered to the chief student affairs officers at the institutions studied. The survey provided a list of student services that were culled from the literature and modified according to the results of a pre-test. The 65 services were grouped into thirteen categories. Respondents indicated if the services were available at the institutions, and if so, indicated on a Likert scale the degree of success in 
attracting adult students to the service. In addition, an open-ended question enabled the respondents to expand upon additional services that were necessary to accommodate adult students.

Surveys were distributed to all 42 targeted institutions. Eight of the 15 (52\%) public colleges returned surveys, and 18 of the 27 (67\%) private colleges reported. Respondents indicated that 50 of the 65 student services listed in the survey were available at the majority of the public institutions, and 40 of the 65 student services were available at the majority of the private institutions. Three services were considered "very successful," 61 were considered "successful" and one service was considered "not successful."

Although there were individual services that adequately met the needs of the adult students, it was determined that modifications are needed for all services listed in the survey. This study also suggested that the four-year undergraduate institutions in Virginia should continually evaluate their student services in order to attract and serve the adult student population. 


\author{
Name of Department \\ Curry School of Education \\ University of Virginia \\ Charlottesville, Virginia \\ APPROVAL OF THE DISSERTATION
}

This dissertation, Student Services for Adult Undergraduate Students at Virginia's Four-Year Institutions, has been approved by the Graduate Faculty of the Curry School of Education in partial fulfillment of the requirements for the degree of Doctor of Philosophy.

Annette Gibbs, Ph.D., Advisor

Samuel E. Kellams, Ph.D.

Robert W. Covert, Ph.D.

Patricia M. Lampkin, Ed.D.

April 21, 1998 


\section{DEDICATION}

This dissertation is dedicated to my parents, Jeanne C. Soule and Hayden M. Soule Jr., without whom this dissertation would not exist. Their unshakable belief in me, their unending support of my aspirations and dreams, and their unconditional love are directly responsible for the person I am today. 


\section{ACKNOWLEDGEMENTS}

There are many people to whom I owe my gratitude. First, I would like to thank my dissertation committee members, Doctors Annette Gibbs, Sam Kellams, Bob Covert, and Pat Lampkin for their support and guidance. Dr. Gibbs, who served as my major advisor throughout my tenure at UVA, always provided valuable advice, direction, and encouragement.

I want to acknowledge and thank Aruna Viswadoss, my friend, fellow student, and dissertation partner, for her unstinting support, invaluable editing skills, and numerous invitations to dinner. My gratitude is also extended to Aruna's husband, Ravichandran Vancheeswaran. On many occasions, he patiently listened to the details of my dissertation and provided me with invaluable comments, encouragement, and prodding.

Last, but certainly not least, special thanks go to my family. My parents Jeanne and Hayden M. Soule who have the utmost faith in me and never fail to tell me so. My sister Terry S. Witowsky; my brother-in-law William E. Witowsky; and my nieces Laura and Kelly have provided me with a refuge from the demands of academia and an unlimited supply of hugs and merts. To my brother scott A. Soule; my sister-in-law Elizabeth C. Soule; and my niece Shelby and my nephew Wyatt 
for their unceasing encouragement and for helping me find the humor in difficult situations. 
TABLE OF CONTENTS

Dedication iv

Acknowledgements $\quad$ V

Table of Contents vii

List of Tables ix

Chapter One: Introduction to the Study 1

Introduction 1

Purpose of the Study 5

Research Questions 6

Expected Outcomes 6

Definition of Terms 7

Methodology 9

$\begin{array}{ll}\text { Summary } & 10\end{array}$

Chapter Two: Review of the Related Literature 11

Demographics 11

Higher Education Environment 14

$\begin{array}{lr}\text { Student Affairs Environment } & 16\end{array}$

Adult Students 19

Student Service for Adult Students 25

Summary 29

Chapter Three: Study Design and Methodology 30

Introduction $\quad 30$

Research Questions 31

The Survey Instrument 31

Validation of the Survey Instrument 33

Administration of the Survey 36

Data Management and Analysis 37

Limitations 40

Chapter Four: Presentation of Data 41

Introduction 41

Description of the Respondents 42

Student Services Currently Available 42

$\begin{array}{ll}\text { Success of the Student Services } & 67\end{array}$

Additional Student Services 99

$\begin{array}{ll}\text { Summary } & 99\end{array}$

Chapter Five: Conclusions and Recommendations 102 
Review of Problem, Literature and Methodology 102

$\begin{array}{ll}\text { Summary of Results } & 104\end{array}$

Conclusions and Recommendations 109

Directions for Further Investigation 128

$\begin{array}{ll}\text { Summary } & 129\end{array}$

$\begin{array}{ll}\text { References } & 130\end{array}$

$\begin{array}{ll}\text { Appendices } & 140\end{array}$

Appendix A: Population in the Study 141

Public Institutions 142

Private Institutions 144

Appendix B: The Survey Instrument 147

Appendix C: List of Survey Pre-test 150

Participants

Appendix D: Cover Letters for the Survey 152

Cover Letter 153

Follow-Up Letter 154

Thank you Letter 155 


\section{LIST OF TABLES}

Table

Page

1 Population Response Rate 42

2 Admissions Services: Mean Percentages of

44

"Yes" Responses

3 Admissions Services: Rank Order Summary

44

4 Admissions Services Population Summary

5 Business Office Services: Mean Percentage of "Yes" Responses

6 Business Office Services: Rank Order Summary

7 Business Office Services Population Summary

8 Counseling Services: Mean Percentages of "Yes" Responses

9 Counseling Services: Rank Order Summary

10 Counseling Services Population Summary 48

11 Financial Aid Services: Mean Percentages 49 of "Yes" Responses

12 Financial Aid Services: Rank Order Summary

13 Financial Aid Services Population Summary 50

14 Food Services: Mean Percentages of "Yes" 51 Responses

15 Food Services: Rank Order Summary 51

16 Food Services Population Summary 52

17 Orientation Services: Mean Percentages of 53 "Yes" Responses

18 Orientation Services: Rank Order Summary 53

19 Orientation Services Population Summary 53 
20 College Personnel Services: Mean

Percentages of "Yes" Responses

21 College Personnel Services: Rank Order

Summary

22 College Personnel Services Population

23 Registration Services: Mean Percentages of "Yes" Responses

24 Registration Services: Rank Order Summary

25 Registration Services Population Summary

26 Student Activities Services: Mean

Percentages of "Yes" Responses

27 Student Activities Services: Rank Order

28 Student Activities Services Population Summary

29 Education Support Services: Mean Percentages of "Yes" Responses

30 Education Support Services: Rank Order Summary

31 Education Support Services Population Summary

32 Residential Life Services: Mean Percentages of "Yes" Responses

33 Residential Life Services: Rank Order Summary

34 Residential Life Services Population Summary

35 Parking and Transportation Services: Mean Percentages of "Yes" Responses

36 Parking and Transportation Services: Rank Order Summary 
37 Parking and Transportation Services Population Summary

38 Miscellaneous Services: Mean Percentages of "Yes" Responses

39 Miscellaneous Services: Rank Order Summary 66

40 Miscellaneous Services Population Summary 66

41 Admissions Services: Public Institutions 68

42 Admissions Services: Private Institutions 69

43 Admissions Services: Total Population 70

44 Business Services: Public Institutions 71

45 Business Services: Private Institutions 72

46 Business Services: Total Population 72

47 Counseling Services: Public Institutions 73

48 Counseling Services: Private Institutions 74

49 Counseling Services: Total Population 75

50 Financial Aid Services: Public 76 Institutions

51 Financial Aid Services: Private 77 Institutions

52 Financial Aid Services: Total Population 77

53 Food Services: Public Institutions 79

54 Food Services: Private Institutions 79

55 Food Services: Total Population 80

56 Orientation Services: Public Institutions 81

57 Orientation Services: Private Institutions 81

58 Orientation Services: Total Population 82

59 College Personnel: Public Institutions 83 
60 College Personnel: Private Institutions

61 College Personnel: Total Populations

62 Registration Services: Public Institutions 85

63 Registration Services: Private

Institutions

64 Registration Services: Total Population 86

65 Student Activities: Public Institutions 87

66 Student Activities: Private Institutions 87

67 Student Activities: Total Population 88

68 Educational Support Services: Public 89 Institutions

69 Educational Support Services: Private 90 Institutions

70 Educational Support Services: Total 91 Population

71 Residential Life Services: Public 92 Institutions

72 Residential Life Services: Private 92 Institutions

73 Residential Life Services: Total 93 Population

74 Parking and Transportation Services: 94 Public Institutions

75 Parking and Transportation Services: 95 Private Institutions

76 Parking and Transportation Services: Total 95 Population

77 Miscellaneous Services: Public 96 Institutions 
78 Miscellaneous Services: Private

Institutions

79 Miscellaneous Services: Total Population

80 Population Summary: Availability and

Degree of Success for Student Services 
CHAPTER ONE

INTRODUCTION TO THE STUDY

Introduction

Adult learners (students over 25 years of age) constitute an increasing percentage of college students in the United States. A recent survey by the Chronicle of Higher Education shows that adult undergraduate students constitute 4.6 million, 37 percent, of all undergraduate college students in the United States (Chronicle of Higher Education, 1997, p. 18). In the Commonwealth of Virginia, the figures compiled by the state Council of Higher Education for Virginia (SCHEV) show that in 1977 of the students who attended the four-year institutions, 95, 528 (39\%) were over 25 years of age. In comparison, the SCHEV figures for 1995 show that of the students who attended the four-year institutions, 148,776 (43\%) were over 25 years of age (SCHEV, 1995).

The presence of these students has had a significant impact upon academic programs and student services originally designed to meet the needs of a student body which was traditionally white, middle or upper class, fulltime residential, and 18 to 24 years old. Adult students bring with them a whole set of service needs that differ significantly from the needs of traditional students (Shearon and Tollefson, 1989). 
This increase in enrollment of older undergraduate students has occurred in response to two national trends: greater numbers of women entering the work force (usually after years dedicated to child rearing) and a growing educational need of American workers for job retraining, advancement, or change (El-Khawas, 1996). Because they are completing course work while answering the numerous other demands of life, they require different kinds of services at different times of the day (Shearon and Tollefson, 1989). The special needs of this population continue to change and this change places significant stress on many of the current services being offered.

Institutional response to new student populations at the undergraduate level has often been inadequate and inappropriate. Many colleges and universities continue to operate as though a college education means 120 credit hours of course work completed by students between the ages of eighteen and twenty-four. In addition, many student affairs practitioners received their degrees at similar institutions and were professionally trained in programs emphasizing the needs of traditional college students. Their training tends to have focused on traditional-age, full-time students who live on campus (Jacoby, 1989).

Rather than anticipating the unique needs of new types of students and then modifying existing programs and creating new ones to respond more adequately to those needs, colleges and universities frequently have attempted to fit 
nontraditional students into traditional programs and services. Institutions have expected new subgroups to comply with existing regulations which were originally formulated for differing other subgroups. The process of adapting student services to meet the needs of a diverse population typically is a gradual one. Adaptation occurs only after certain population groups have grown to the extent that they become vocal about their needs and "seek group-conscious forms of assistance" (El-Khawas, 1996, p. 65). Once the need is known, institutional response is slow to develop. It is often only after the nontraditional students have been on campus for awhile and have experienced frustrations with programs and services geared toward traditional students that universities and colleges begin to respond to these new students in a reactive manner or in a remedial fashion (El-Khawas, 1996).

Ackell (1986) categorizes institutional response to adult undergraduate student needs into three levels: laissez-faire, separatist, and equity. The laissez-faire level is when the institutions' reactions to the introduction of adult students is to remove a few barriers and constraints but otherwise let the students function as best as they can within the system. The next level of separatist is when the institutions segregate the adult students from the traditional-age student body and provide them with separate, specifically developed programs that are typically inferior in quality. The last level, and the most 
advanced, is the equity stage where institutions take significant steps to treat all students fairly and to provide the same quality of experience to all students. Research on the characteristics of adult undergraduate students by Miller and Winston (1991) has documented some differences between adult learners and traditional-aged students that emphasizes the need for appropriate institutional response. Adult students are more likely to be financially independent and often carry additional financial and emotional responsibilities as a result of their roles as spouses and/or parents. They bring to the campus a wide range of life and career experiences and often seek to integrate their education with those experiences immediately rather than in the future. Their class schedules and educational activities usually compete with their job, family, community and personal commitments. Colleges do not always make adults feel welcome as full members of the campus community. Their basic needs, such as family student housing and child care, frequently are not adequately met. Adults often find that career counseling, orientation, academic advising, health services, and social and recreational activities are geared for traditional-age students. Opportunities to interact with peers may be limited; services may not be available at hours when most adults are on campus; and family-oriented activities are often lacking (Miller \& Winston, 1991). 
As the characteristics of students pursuing higher education continue to become more diverse, universities and colleges must adapt to meet the needs and goals of these students. In this time of public consumerism and requirement of institutional accountability, the responsibility of adaptation must shift from the students to the institutions. The colleges and universities that do not meet this challenge will be faced with lower enrollments, financial insolvency, and, ultimately, questions of survival (Jacoby, 1993). Understanding the factors that affect the adult students' educational experience is one way to begin addressing the issues of enrollment, retention, accountability and public consumerism presently facing universities.

Purpose of the study

The purpose of the study was to discover the student services available to adult undergraduate students attending Virginia's 15 public and 27 private undergraduate four-year colleges, to determine which of these services were successful or unsuccessful in attracting adult students and to ascertain if there were additional student services needed to accommodate their students.

For the purpose of the study, an adult student was defined as being at least 25 years old and enrolled in fullor part-time undergraduate course work in any program at 
Virginia's four-year colleges. Research on these issues is beneficial to colleges and universities in their efforts to evaluate their current programs, policies, and procedures for determining appropriate student services that respond to the special needs of the adult student population.

Research Questions

This study examined three primary research questions:

1. What are the student services currently available to adult students attending the four-year colleges in Virginia?

2. Which of the available student services are successful and which are unsuccessful in attracting adult students?

3. What additional student services are needed to accommodate adult students?

Expected Outcomes

It is anticipated that the data from the study will provide student affairs administrators with a reference for examining the services that their own adult students need and want. Study and analysis of institutional responses to adult students' needs will result in enhanced understanding of the issues faced by the institutions and the adult learners. Knowledge about adult student concerns is greatly 
needed with the burgeoning adult populations at universities today

\section{Definition of Terms}

Adult Education: a process whereby persons who no longer attend school on a regular full-time basis...undertake sequential and organized activities with the conscious intention of bringing about changes in information, knowledge, understanding, or skill, appreciation and attitudes; or for the purpose of understanding identifying or solving personal or community problems (Liveright and Haygood, 1969, p. 8).

Adult Learners: An individual who is over 25 years of age, and who is enrolled either full-or part-time course work in any program at Virginia's four-year colleges.

Student Services: Institutional programs or policies that are designed to enhance, support, complement, or facilitate the educational experience(s) of students. Adult Student Support System: An interconnecting structure of services offered to adults to enhance the educational experience. System components include the following services: (a) appraisal, (b) orientation, (c) consultation, (d) extracurricular, (e) environmental, (f) organizational, and (g) academic (Cohen and Brawer, 1989). Appraisal Services: These include: (a) disseminating information to prospective students (e.g. brochures, advertisements), (b) admissions information, (c) financial 
aid information, (d) pre-entrance contacts, (e) assessments of prior learning (e.g. portfolio analysis, career achievements), and (f) enrollment procedures.

Orientation Services: These include specific programs that provide an introduction to the institutional programs for adults and individual interpersonal contacts.

Consultation Services: These include: (a) personal counseling, (b) career counseling, and (c) academic counseling. Extra-curricular Services: These include: (a) student government, (b) organizations, (c) activities, and (d) opportunities to integrate the student's family into the educational experience.

Environmental Services: These include: (a) extended hours and services of administrative offices, library, bookstore, dining areas, and other support operations; (b) employment services; (c) specialized registration; (d) health services/clinic; (e) security/safety services, (f) child care, and (g) student insurance.

Organizational Services: These include: (a) modification of administrative services (e.g. student input, institutional research); (b) recognition of adult peerage by faculty (e.g. self-directed learning, modified teaching methods designed to accommodate adult needs and prior experiences, inclusion of various learning styles in material presentation, student-instructor contract learning, recognition of adult 
motivations for enrollment); and (c) information on institutional services, activities, and resource centers. Academic Services: These include: (a) learning skills support (e.g. remedial/developmental classes, tutoring, workshops, reading and writing laboratories); (b) class scheduling alternatives (e.g. time configuration); (c) noncampus based degrees: (d) distance learning (e.g. correspondence courses, directed studies, Internet or webbased, television, video, program learning materials, electronic data); (e) access to materials (e.g. required class materials and support); (f) faculty orientation to teaching adults (e.g. desire to teach adults, teaching styles, demeanor, facilitation, recognition of faculty as student personnel professionals representing the institution) . Chief Student Affairs Officer: Those individuals who have supervisory and management responsibility for the planning, development, and implementation of student services at each of the four-year colleges and universities in Virginia.

\section{Methodology}

This was a descriptive study using quantitative methods. The population for this study consisted of the chief student affairs administrators at the four-year undergraduate institution in Virginia. A self-reporting survey instrument was developed by the researcher generated 
from information identified through a review of research and related literature. Data collection was accomplished by mailing the instrument to the population. The responses of the population were analyzed by the type of institution (i.e., public and private).

\section{Summary}

This study describes the student services available to adult students at the Commonwealth of Virginia's 15 public and 27 private undergraduate four-year colleges and universities. The primary goals of this study were to identify which student services are offered at the institutions, to determine which services are considered successful or unsuccessful, and to ascertain if there are additional services that are needed to better serve the adult student population. 
CHAPTER TWO

REVIEW OF THE RELATED LITERATURE

The concepts of adult education provide student affairs administrators with information concerning the needs, preferences, and orientations of adult students (students over the age of 25). This chapter portrays the literature in the areas of demographics, higher education environment, student affairs, adult student characteristics, and student services for adult students.

\section{Demographics}

According to Crouch (1995), the United States has been undergoing several significant demographic revolutions simultaneously. The country has always reflected a pyramidshaped population structure when viewed by age, with each new generation larger than the preceding generation. There has always been a pool of young entry-level workers who were better educated, more skilled, and economically better off. But that is no longer the case. The United States has begun to square the pyramid, with the generation of middle-aged adults becoming as large as the generation of youth. In 1990, there were 43 million people in the United States between the ages of twenty-five and thirty-four and only 25 million people between the ages of forty-five and fiftyfour. Projections for the year 2010 reveal a drop to 38 
million people between the ages of twenty-five and thirtyfour and a dramatic growth to 44 million for people between the ages of forty-five and fifty-four. The 1990 Census reveals that thirty-three states had fewer youth in 1990 than they did in 1980 (U.S. Bureau of the Census, 1992). The Commonwealth of Virginia is one of the states experiencing this trend. In 1980, Virginia had over 1.5 million people under the age of 18. In 1990, the number had decreased by 200,000 (U.S. Bureau of the Census, 1982; U.S. Bureau of the Census, 1992).

The dramatic growth in the entry-level work force population has stopped. The fertility rate of "baby boomers", born between 1946 and 1964, was below replacement level, and the youngest baby boomers are now older than 30 and moving out of their child-bearing years. Fewer of the new population group of child-bearing age exist (Crouch, 1995) .

A new reality is that, while the base of the pyramid has stopped growing, the top of the pyramid is ballooning. The young adult population, ages 25 to 34 , grew by $73.8 \%$ between 1970 and 1990 but is projected to decline by $11.6 \%$ between 1990 and 2010. Meanwhile, the mature adult population, ages 45 to 54, grew by only 8.9\% between 1970 and 1990 but is projected to grow by $74.8 \%$ between 1990 and 2010 (Crouch, 1995, p. 25). 
As a result of this demographic shift, adult students currently make up nearly 50 percent of all college enrollments in the United States. This represents a $50 \%$ growth rate of adult students in the past 20 years, a major factor in the steady rise in college enrollments over recent decades. Enrollment for all students has risen from 8.5 million in 1970 to 14.2 million in 1995 (Chronicle of Higher Education, 1997, p. 10). The 1995 enrollment figure includes a significantly greater proportion of adult students than higher education has ever experienced. Even the post-war students using the G.I. bill only raised the percentage of adult students to 30\% (Brubacher \& Rudy, 1976) .

The adult student population has experienced consistent growth at the undergraduate level for the last 10-15 years. It is also growing faster than the traditional 18-24 year old student group. For example, from 1975 to 1995, the number of students over 30 has more than doubled to 3,000,000. This population is projected to grow by $16 \%$ by the year 2000, while the traditional student group will remain constant (Gifford, 1992, p. A12).

The changing demographics of the United States and, more specifically, the changing undergraduate student population on university campuses indicates that colleges and universities should modify their operations to address 
the needs of the nontraditional student. Colleges and universities must address the needs of emerging student populations or risk alienating an important student segment (O'Connor, 1994). In this era of accountability, the burden of adaptation must shift from the students themselves to the institutions. Those institutions that fail to meet this challenge will find their enrollments, their financial solvency, and their existence threatened (Jacoby, 1993).

\section{Higher Education Environment}

The number of traditional-age college students has declined by five percent from 1993 to 1997 although the number of students is projected to increase by 14 percent from 1998 to 2005. While traditional-age student enrollment (percentage) has decreased, the adult student population has been increasing from 5.1 million in 1985 to an estimated 6.5 million in 1993. The proportion of students 25 years old and over rose from 41.6 percent in 1985 to 44.3 percent in 1993 (Gerald \& Hussar, 1995, p. 11).

This increase in the adult student population can be attributed to many factors but primarily to that of job/career issues. Aslanian (1995) reported that 90\% of adults state that they return to school because of career changes which forces them to seek additional education to compete in the job market. Although the community colleges 
do an admirable job of keeping abreast of changing employment trends and tailoring their curricula to meet the need of new skills, they do not serve the entire population of adult students (Cohen \& Brawer, 1989).

As it has evolved in America, higher education includes much more than the availability of a program of studies towards a degree. Education for life (Cross, 1981) means more than advanced courses in the three "Rs". Historically, American higher education has striven to meet the academic and developmental needs of its students (Chickering \& Havighurst, 1981). Colleges and universities provide housing, food services, developmental programs, leadership training, and much more outside the academic curriculum. Higher education continually strives to foster an environment which encourages students to make full use of their academic and developmental opportunities (Cross, 1981)

\section{Student Affairs Environment}

The student affairs profession plays a significant role in providing an environment that fosters academic and developmental opportunities for all students. Higher education in the United States is characterized by constant change to meet the fluctuating needs of society. In responding to these changing needs, student affairs has assumed a number of important roles within colleges and 
universities. The role has evolved from that of disciplinarian to coordinator to educator (Garland \& Grace, 1993).

In the early colonial period, the faculty was empowered to act in loco parentis, and the style of discipline was paternalistic, strict, and authoritarian. Religious activity, a strict moralistic discipline, and a classical curriculum dominated student life and the activities of the students. Discipline was the student affairs approach in this period, but it began to change with students' increasing numbers and colleges' growing complexity. It was at this time that the notion that certain members of the college community would be responsible for shaping students' behavior and dispensing discipline took root (Cowley, 1949). From the disciplinarian role, the student affairs profession shifted to the role of coordinator. With the passage of the Morrill Land Grant Acts of 1862 and 1864, institutions expanded their purposes to include education for responsible, enlightened citizenship as well as vocational training. With the enlarged curriculum came a more diverse student population and an increased number of student activities (Garland \& Grace, 1993). As a result, higher education institutions began creating positions such as Dean of Men or Dean of Women that are now recognized as student affairs administrators (Fenske, 1989). These 
positions were given the charge of coordinating the student activities and services such as student health, career placement, counseling and testing, housing, food services, and Greek activities (Cross, 1981).

More recently, the student affairs profession has moved to the role of "educator" (Garland \& Grace, 1993). The growth of the "personnel guidance" movement after World War I gave student affairs members a greater degree of professionalism and direction. It prompted the development and application of new psychological and pedagogical theories which supported the need for a student affairs profession.

Further evolution in the bases of student services occurred in the late sixties and early seventies when a student development model was articulated by several proponents (Miller and Prince, 1976). Sanford (1967) argued that colleges and universities should adopt as their chief mission the individual development of each student and should intentionally promote a "developmental community" in which students were challenged by new experiences and ideas and provided support to meet the challenges.

The latest development in the evolution of student affairs emerged in 1994 when the American College Personnel Association (ACPA) published The Student Learning Imperative: Implications for Student Affairs. This 
declaration called for "affirming learning and personal development as primary goals of undergraduate education" $(\mathrm{ACPA}, 1994, \mathrm{p} .4)$. It proposed a need for a rededication to the mission and values of college student affairs. It also affirmed the need to work more closely with faculty and to eliminate the extracurricular versus curricular conflicts in higher education. One of the tasks facing student affairs is to translate the learning emphasis into meaningful approaches to program design and implementation (Bloland, Stamatakos \& Rogers, 1996; Caple, 1996).

As student affairs professionals respond to continuously changing environments with diverse student populations, the large and growing influx of adult students has brought a change in that environment (Terrell, 1990). Although traditional students continue to grow in the current environmental support system, adult students bring with them a different set of needs (Grottkau \& Davis, 1987; Neal, 1985).

\section{Adult students}

Cross (1980) defined the adult student as an adult who returns to school full-or part-time while maintaining commitments in the areas of employment, family, and other adult obligations. These students also may be referred to as non-traditional students, re-entry students, returning 
students, and adult learners. While these older students share classroom space and educational experiences with the traditional-age students (18-24), their developmental needs, issues, and stressors differ considerably from those of their younger peers. In addition, men and women may vary somewhat in their motivations for returning to school, the pressures and challenges they face as adult students, and the types of student services desired. Because these factors differ considerably from the "traditional-aged" students, all aspects of the college environment must be reconsidered to respond to this growing student population (Benshoff, 1991).

Numerous studies have reported differences between traditional-aged students and adult students in terms of identity, motivation, familiarity with expectations of the academic system, obligations and responsibilities, and learning styles (Apps, 1981; Kasworm, 1980; Knowles et. al., 1984; Sheehan, McMenarmin \& McDevitt, 1992; Bean \& Metzner, 1985; Rubenson, 1989).

A number of factors characteristically separate nontraditional students from younger college students. Adult learners tend to be achievement oriented, highly motivated, and relatively independent with special needs for flexible schedules and instruction appropriate for their developmental level (Benshoff \& Lewis, 1992). Financial and 
family concerns are two of the biggest considerations that impact on the adult student experience (Richter-Antion, 1986). Additional factors that distinguish nontraditional students from traditional students include:

- stronger consumer orientation (education as an investment)

- multiple non-school-related commitments and responsibilities.

- lack of an age cohort, and

- limited social acceptability and support for their student status (operating outside of traditional adult roles) (Richter-Antion, 1986).

Women constitute the fastest growing segment of the adult education movement at $65 \%$ of the adult student population (Aslanian, 1995). Solmon and Gordon (1981) found more adult women than men enrolled in post-secondary institutions. The adult women tend to be older than adult male students and are more likely to move at a slower pace academically than their male counterparts (Mishler, Fredrich, Hogan, \& Woody, 1982).

Cross (1981) has indicated that there are also socioeconomic differences between the older and traditional age student. Typically, degree-seeking adults have come from working-class backgrounds and have been for the most part, first generation college students whose parents did 
not attend college. Parents of traditional-age college students have tended to be better educated. At the same time, however, the adult students have tended to be better educated and hold better jobs than their peers do in the general population (Shipp and McKenzie, 1981).

Solmon and Gordon (1981) found numerous differences between the adult and traditional student in their reasons for attending a particular college. The adult students, more often than the traditional students, tended to indicate the desire to live at home, the special educational programs offered at the institution, the low tuition, and the availability of financial aid as being important in their selection of college. Traditional students tended to indicate that the academic reputation of the college was more important than the factors above.

Adult students need many different kinds of support and assistance from family, friends, and institutions of higher education. Research evidence suggests that "both sexes have difficulties juggling the roles of student, worker, and family member" (Muench, 1987, p. 10). Adult students need help in building their self-confidence as students, in acquiring or refreshing study skills, and in managing their time and other resources while in school. In addition, adult students benefit from opportunities to interact with their peers and need to be actively involved in the 
educational process through sharing their relevant work and life experiences (Knox, 1986).

There are many reasons why adult students return to school. When adult learners were first studied, Houle (1961) found that adults learn for one or more of the following reasons: they may have a specific career goal in mind and need specific skills to meet that goal; a person may want to go to school to socialize-find a new husband or wife, make new friends; or a person may want to learn solely for the sake of learning. Houle felt that this was adequate to explain that adult students could be categorized into three categories-the goal oriented, the socializer, and the lover of learning. Subsequent studies have discovered the complexities of motivation for adults returning to school. Many non-traditional students come back to school to complete educational pursuits they began years before as traditional-age students. They may have dropped out of education for a number of reasons, including financial considerations, competing responsibilities, and lack of focus, motivation, and maturity. Changing job requirements or career changes often force adults to get additional education to survive or advance in the job market (Aslanian \& Brickell, 1988). Other major reasons that adults return to college campuses include family life transitions such as 
marriage, divorce, or death, changes in leisure patterns, and self-fulfillment (Aslanian \& Brickell, 1988).

However, the primary reason for adults returning to college is job/career changes. In a study by Aslanian (1995), 90\% of the adults reported that they returned to school because of job/career issues. Adults return to school to gain new competencies to enter, change, or advance in their careers. Many also learn just to keep up with current jobs. The American economy has been changing rapidly from an industrial base to an information and service base. As it does, it eliminates large numbers of industrial jobs. Workers from declining industries are being forced to retrain to fit available service and technological jobs. Quite often, that retraining requires post-secondary education (Naylor, 1988). 


\section{Student Services for Adult Students}

With the new wave of adults on campuses that traditionally have served younger students, services provided to students have had to broaden and change. Because adult students are under pressure from competing responsibilities and have different needs, it is a mistake to treat adult students and younger students in the same manner. Attention to adult student services cannot only enhance adults' learning experiences, but also influence entry and persistence (Schlossberg, Lynch, and Chickering, 1989)

The majority of research that pertains to student services for adult students comes from samples drawn from community colleges (Brown \& Linnemann, 1995). In particular, Baker (1991) studied the student services available to adult students at Virginia community colleges, finding that the majority of services were identified as important and were offered at appropriate times for evening students.

Few studies have examined student services at four-year institutions. In a University of Georgia study, Kasworm (1980) discovered significant differences between older and younger undergraduates' use of, perceived needs for, and satisfaction with services. Older students indicated a lower need for the services investigated. Okun, Taub, and Witter 
(1986), using a sample from a large southwestern public university, found student services use inversely related to age, and major barriers to student service use the same regardless of age or sex. Focusing on institutional responsiveness at the University of Massachusetts-Amherst, which serves primarily traditional-aged students, Greenland (1988) found that widespread acceptance of adult students did not exist although the institution was described as being "potentially responsive" to adult students. A portion of the Greenland study measured adult students' satisfaction with services offered. She found the adult undergraduate rate of service use to be low and satisfaction with individual services in the "neutral-satisfied" range. Merriam and Caffarella (1991), Thiel (1984), Greenland (1988), and Kasworm (1980) recommend further research into the adequacy and appropriateness of adult student services. Historically, institutional accommodation of the students who are considered to be outside of the "norm" has always been minimal and peripheral (Jacoby, 1993). If an institution is truly committed to a diverse student body, that institution must adjust its policies, practices, and programs to meet the needs of all of its students instead of expecting the students to adjust to the institution.

Administrators and researchers have used various methods for categorizing institutional response to students' 
needs. Ackell's (1986) model is the benchmark for understanding the process of institutional adaptation to the presence of adult students and is useful for understanding the broad scope of the changes necessary in the majority of institutions. Ackell envisions the process of institutional adaptation and change as three stages that range from a rather primitive organizational stage, through a more specialized type of adaptation, to a final stage in which the institution treats all its students in an equitable manner.

The first level is the "Laissez-Faire" stage. When institutions first begin to attempt to cope with the advent of adult students, the initial reaction is primarily to remove a few of the obvious barriers or artificial constraints that may apply to adults such as age requirements for admission, required parental consent forms, etc. This allows the adults to function as best they can within a system that neither hinders nor helps them. According to Jacoby (1993), it is unknown if students enrolled in institutions in this category are consistently less satisfied with their college experience than others or whether some groups leave the institution at higher rates. Ackell's (1986) next level of institutional awareness of adult student needs is the "Separatist" stage. Students at this level, the adult students are, in essence, 
segregated from the traditional-age student body and provided with separate, specifically developed programs which are typically given lower priority and status than the programs offered to the traditional-age student population. Adult students attending institutions in this category feel that they are marginal rather than integral members of the campus community. They are also consistently less satisfied with their educational experience, and leave the institutions at a higher rate (Jacoby, 1993).

The last level of Ackell's (1986) model of institutional involvement with adult students is the "Equity" stage. These institutions promote active recruitment of adult students, provision of degree credits for prior learning, and student services such as registration, financial aid, personal and career counseling, advising, day-care, and orientation sessions. Students attending colleges and universities engaged in this level of involvement feel included as members of the campus community and are so recognized (Jacoby, 1993).

\section{Summary}

This literature review provides the framework from which the study is developed. The research documents limited examination of adult students' needs addressed by the student affairs administrators at the four-year 
institutions of higher education. The research that is available concerns the service needs of adults in the community colleges. Four-year institutions, also, should address the unique service needs of this diverse student population. To not do so is to miss an obligation to provide adequate education to a segment of the population that continues to expand and comprise larger percentages of student enrollment for colleges and universities in the Commonwealth of Virginia. 
CHAPTER THREE

STUDY DESIGN AND METHODOLOGY

Introduction

This was a descriptive study using quantitative methods to discover the student services which are available to adult undergraduate students (students over the age of 25), to determine the reasons administrators perceive these services to be successful or unsuccessful in attracting adult students and to ascertain the additional services that should be available to these students. The study population consisted of the chief student affairs administrators at the 15 public and 27 private four-year undergraduate institutions in Virginia as identified in the state council of Education for Virginia (SCHEV) publications: Senior Public Colleges and Universities, 1997 (a) and Private NotFor-Profit Institutions of Higher Education, 1997 (b). The population was accessible and its size manageable, since all members are from the state of Virginia.

Completed surveys were received from eight of the fifteen public institutions constituting a response rate of 53 percent and 18 of the 27 private institutions constituting a response rate of 67 percent. This represented a total population response rate of 26 (n) of 42 
(N), or 62 percent of the population. A listing of the population is provided in Appendix A.

\section{Research Questions}

The survey addressed the following three research questions:

1. What are the student services currently available to adult students attending the four-year colleges in the Commonwealth of Virginia?

2. Which of the available student services are successful and which are unsuccessful in attracting adult students?

3. What additional student services are needed to accommodate adult students?

\section{The Survey Instrument}

A self-reporting survey instrument (Appendix B) was developed by the researcher to explore in greater detail the research questions included in the study. This instrument was generated from information identified through a review of research and related literature (Baker, 1991; Shriberg, 1984; Rentz \& Saddlemire, 1988; Spratt, 1984; Brown \& Linnemann, 1995).

The two part survey was administered to the chief student affairs officer at each public and private 
undergraduate institution in the Commonwealth of Virginia. The instrument was designed to fulfill the purposes of the study and to answer the research questions.

The first part of the survey was completed by all respondents. The section listed 65 student services that were identified from the literature. The respondents were asked to indicate if the student service listed was available currently to adult students at their institutions by circling the appropriate response. The response options were a "yes" to indicate that the service was currently available or a "no" to indicate that the service was not currently available.

If the respondent circled "yes" for the service in the first part of the survey, the respondents were then prompted to rate the success of the service in attracting adult students to their institution. A Likert scale of "very successful," "successful," and "not successful" was provided for each of the 65 survey items.

The last part of the survey was used to collect information about additional services that were needed to accommodate adult students as determined by the respondents. This section was left blank by many of the respondents.

$$
\text { Validation of the Survey Instrument }
$$

Before the survey was administered to the population it was pre-tested with four student affairs administrators from 
two public and two private institutions. After the respondents completed the survey, the pre-test team was asked to assess the adequacy of response options and the overall comprehensibility and difficulty of completing the survey. In addition, they were interviewed to determine the face validity of the instrument through the following questions:

1. Were the instructions clear and sufficient?

2. Did the survey provide a comprehensive listing of student services that could be provided at four-year undergraduate colleges in Virginia?

3. Should any items be eliminated because they are (a) irrelevant, (b) misleading, or (c) redundant?

4. Is the survey of reasonable length?

5. Were there any questions, comments, or general suggestions for changes and/or improvements?

The pre-test respondents made several suggestions to improve the instrument. In response to question \#1 ("were the instructions clear and sufficient?"), all administrators stated that the instructions were clear and sufficient, although one respondent suggested a change in the format of the paragraph for improved visual presentation. The instructions were modified in their appearance. In response to question \#2 ("did the survey provide a comprehensive listing of student services that could be provided at four- 
year colleges in Virginia?") all respondents stated that the list was comprehensive. The pre-test team suggested that several items listed as potential student services be reworded. It was also recommended that the phrase "for adult students" be dropped from several services because they could also be provided for traditional students. Since there would be no differences in the services for traditional and adult students the specification was not necessary. Some service items were deleted and several new items were added as the result of the pre-test team's advice. The number of services listed in the instrument remained the same at 65 items.

In response to question \#3 ("should any items be eliminated because they are (a) irrelevant, (b) misleading, or (c) redundant?") the pre-test team made several recommendations. In the category of "College Personnel," the pre-test respondents recommended the elimination of an item because it was redundant. The pre-test team also recommended the elimination of an item in the category of "Educational Support" because it was considered irrelevant. The pre-test respondents all answered in the affirmative in response to question \#4 ("was the survey of reasonable length?"). The brevity of the instrument was particularly important considering that chief student affairs officers tend to be subject to severe time 
constraints due to myriad job responsibilities. A lengthier and more complex questionnaire might have been perceived as an imposition and, therefore, served to reduce the response rate.

The administrators responded to question \#5 ("are there any questions, comments, or general suggestions for changes and/or improvements?") by suggesting a change in the heading for the Likert scale from "Degree of Success" to "success in attracting adult students". The original title was too vague and did not capture the intent of the research question.

The names of the individuals serving on the pre-test team are provided in Appendix C.

\section{Administration of the Survey}

The participants in the public and private undergraduate institutions received a cover letter dated January 12, 1998, on official stationary from the Center for the Study of Higher Education and signed by the Director of the Center and the researcher. This letter introduced and described the proposed study, requested participation, and explained the survey instrument accompanying the letter. Participants were requested to return the completed instrument as soon as possible and a response deadline of ten days from the anticipated date of receipt was indicated. 
A pre-addressed, stamped envelope was supplied for the respondents' convenience. The instrument was distributed to the population by the United States mail.

Approximately two weeks later, on February 3, 1998, a follow-up letter was mailed to the chief student affairs officers participating in the study who had not yet returned the completed survey. This letter requested that they return the instrument within the next two weeks. A week after the deadline, telephone calls (or e-mail messages if appropriate) were made to the participants who had not returned the completed questionnaire. During this final follow-up an offer was made to supply replacement instruments via mail or to record the respondents' responses over the telephone. Two respondents requested that new surveys be sent to their offices.

Responses from the initial mailing and follow-up procedures were combined to form the database for the study. Each participant received a "thank you" letter after the completed surveys were returned to the researcher. Copies of the cover letter, the follow-up letter, and the "thank you" letter are included in Appendix D.

\section{Data Management and Analysis}

The returned instruments were checked for completeness and usability. All questionnaires were usable and the data 
were coded in preparation for analysis. Tabulation of raw frequencies, percentages, and means for each item on the survey permitted the researcher to group the data according to various categories for further analysis.

The collected quantitative data were analyzed using several of the computer subprograms available with the Statistical Package for the Social Sciences (SPSS for Windows Version 7.5). The subprogram "Frequencies" was used to process that data first, to provide information on the distribution, proportionality, variability, and central tendencies of the variables, and to note coding errors or other problems in the data. Information derived from this initial treatment of the data was also used for descriptive purposes.

Totally, thirty-nine tables were constructed to present the data. Three tables were constructed for each category of student services. The mean percentages of "yes" responses regarding the student services for the public and private institutions were presented in the first table. A comparison of the rank order summary of the public and private institutions was produced in the second table. The rank order summary of the total population was the final table. The data from these tables answered research question \#1 ("what are the student services currently available?"). Frequencies and percentages were computed for 
each of the identified items of the survey instrument. These data are reported in Tables 2-40. When summarizing the data for availability, the criterion of 50\% was used to denote a majority of the population.

In response to the second research question determining the success in attracting the adult students to the available student services, the 65 items were further analyzed. Each respondent was asked to rate the degree of success using a Likert scale including the scales of "very successful" (VS), "successful" (S), and "not successful" (NS) •

Data were presented in thirty-nine tables, three per category, similar to those designed to answer the first research question. Percentages for the public and private institutions were reported in the first table. A rank order summary of the responses from the public and private institutions was presented in the second table while the rank order summary of the responses of the population was listed in the last table. These data are reported in Tables $41-79$.

Finally, an open-ended question enabled the respondents to list additional services that were necessary to accommodate adult students. The responses are provided on page 99. 


\section{Limitations}

\section{Participants}

The participants of this survey are the Chief student Affairs Administrators at four-year public or private colleges and universities. They represent a very small, albeit important, segment of the student affairs professional population. Geographical Area

The survey was distributed to public and private fouryear institutions in Virginia. The findings may not be generalizable to other states. Identification of Student Services

The survey used in this study included a listing of the various student services available to adult undergraduate students in public and private four-year colleges. It is possible that some services were omitted. Every effort was made to present opportunities for the respondents to provide additional information in an attempt to list all possible student services. 
CHAPTER FOUR

PRESENTATION OF DATA

Introduction

The purpose of the study was to describe the student services that were available to adult students in the public and private undergraduate institutions in the Commonwealth of Virginia. The following questions were addressed in the study: 1) What are the student services currently available to adult students attending the four-year undergraduate colleges in Virginia? 2) Which student services offered are considered successful in attracting adult students? 3) What additional student services are needed to accommodate adult students?

The survey was administered in January 1998, via United States mail to 15 public and 27 private undergraduate institutions. The 42 individual respondents were asked to complete the survey and return it in a self-addressed stamped envelope. Officials at eight of the 15 public institutions returned the completed survey for a response rate of 53 percent and representatives from 18 of the 28 private institutions completed the survey for a response rate of 67 percent. The total response rate was 62 percent. Responses to the survey were coded, entered, and verified by the researcher for storage and analysis on the 
SPSS for Windows Version 7.5 computerized statistical package. This chapter provides a description of the survey responses and includes data which correspond to each of the research questions.

\section{Description of the Respondents}

A summary of the response rate for the total population is presented in Table 1 .

TABLE 1

POPULATION RESPONSE RATE

\begin{tabular}{|l|c|c|c|}
\hline & $\begin{array}{c}\text { Public } \\
\text { Institutions }\end{array}$ & $\begin{array}{c}\text { Private } \\
\text { Institutions }\end{array}$ & Total \\
\hline Number of Surveys Mailed & 15 & 27 & 42 \\
\hline Number of Surveys Returned & 8 & 18 & 26 \\
\hline
\end{tabular}

Completed surveys were received from 8 public institutions and 18 private institutions representing a 53 percent and 67 percent return rate respectively.

\section{Student Services Currently Available}

The data for research question \#1 identified the student services currently available to adult students attending the four-year undergraduate institutions in the Commonwealth of Virginia. The population's responses as to whether or not the 65 listed student services are available at their respective institutions are summarized in Tables 2 through 36. The data in each table represent a "yes" 
response to each item indicating that the listed service is available at the institution. Only "yes" responses are reported in the tables. The data for each student service category from the survey are summarized in each group of tables.

Three tables are provided for each category of student services. The percentages of "yes" responses of the public and private institutions are summarized in the first table. A rank order summary of the student services for the public and private colleges is provided in the second table. The third table summarizes the rank order for the total population.

Admissions Services: Tables $2-4$

Responses to the admissions services categories of the survey are reported in Tables 2 through 4 . The mean percentages of the "yes" responses of public and private institutions for items 1 through 8 on the survey are summarized in Table 2. A "yes" response indicated that the service is available at the institution.

Table 2

Admissions Services: Mean Percentages of "Yes" Responses 


\begin{tabular}{lcc}
\hline ITEM & $\begin{array}{c}\text { PUBLIC } \\
\text { INSTITUTIONS }\end{array}$ & $\begin{array}{c}\text { PRIVATE } \\
\text { INSTITUTIONS }\end{array}$ \\
\hline Recruitment materials & $38 \%$ & $73 \%$ \\
Direct Recruitment of Adults & $50 \%$ & $71 \%$ \\
Personnel recruitment visits & $63 \%$ & $47 \%$ \\
Special admissions criteria & $43 \%$ & $47 \%$ \\
Advanced credit & $50 \%$ & $67 \%$ \\
Part-time degree & $71 \%$ & $77 \%$ \\
Admissions office open & $38 \%$ & $57 \%$ \\
Admissions access via computer & $88 \%$ & $87 \%$ \\
\hline
\end{tabular}

A rank order summary of the admissions services for the public and private institutions is provided in Table 3. Table 3

Admissions Services: Rank Order Summary

\begin{tabular}{cclccl}
\hline & \multicolumn{3}{c}{ PUBLIC } & \multicolumn{3}{c}{ PRIVATE } \\
\hline RANK & $\%$ & ITEM & RANK & $\%$ & ITEM \\
\hline 1 & $88 \%$ & Access computer & 1 & $87 \%$ & Access computer \\
2 & $71 \%$ & Part-time degree & 2 & $77 \%$ & Part-time degree \\
3 & $63 \%$ & Personnel recruit & 3 & $73 \%$ & Recruit material \\
4 & $50 \%$ & Direct recruit & 4 & $71 \%$ & Direct recruit \\
4 & $50 \%$ & Advanced credit & 5 & $67 \%$ & Advanced credit \\
6 & $43 \%$ & Special criteria & 6 & $57 \%$ & Access office \\
7 & $38 \%$ & Recruit material & 7 & $47 \%$ & Personnel recruit \\
7 & $38 \%$ & Access office & 7 & $47 \%$ & Special criteria \\
\hline
\end{tabular}

Table 4 displays the rank order summary of the total population's responses regarding the available admission services.

Table 4 Admissions Services Population Summary 


\begin{tabular}{ccl}
\hline RANK & $\%$ & ITEM \\
\hline 1 & $87 \%$ & Access to office via the computer \\
2 & $75 \%$ & Part-time degree available \\
3 & $64 \%$ & Direct recruitment of adult students \\
4 & $61 \%$ & Advanced academic standing for work/training \\
5 & $61 \%$ & Recruitment material for adult students \\
6 & $52 \%$ & Personnel recruit visit with adults \\
7 & $50 \%$ & Access to the office during evenings \\
8 & $46 \%$ & Special admissions criteria for adults \\
\hline
\end{tabular}

The majority of the public and private institutions reported that access to the admissions office via the computer and part-time degree programs as identified in the survey are currently provided at their institutions. Approximately 60\% of the surveyed institutions provide direct recruitment of adult students, advanced credit for work or training experience, and recruitment material directed towards adult students. Business Office Services: Tables 5-7

Responses to the business office services category of the survey are reported in Tables 5 through 7 . The mean percentages of the "yes" responses of the public and private institutions for items 9 through 11 of the survey are summarized in Table 5. A "yes" response indicated that the service is available at the institution.

Table 5

Business Office Services: Mean Percentages of "Yes" Responses 


\begin{tabular}{lcc}
\hline ITEM & $\begin{array}{c}\text { PUBLIC } \\
\text { INSTITUTIONS }\end{array}$ & $\begin{array}{c}\text { PRIVATE } \\
\text { INSTITUTIONS }\end{array}$ \\
\hline Tuition Installment Plan & $88 \%$ & $93 \%$ \\
Access to Business Office & $25 \%$ & $33 \%$ \\
Access via computer & $50 \%$ & $33 \%$ \\
\hline
\end{tabular}

Table 6 shows the rank order summary of the business office services for the public and private institutions. Table 6

Business Office Services: Rank Order Summary

\begin{tabular}{cclccl}
\hline \multicolumn{2}{c}{ PUBLIC } & \multicolumn{3}{c}{ PRIVATE } \\
\hline RANK & $\%$ & ITEM & RANK & $\%$ & ITEM \\
\hline 1 & $88 \%$ & Tuition Install & 1 & $93 \%$ & Tuition Install \\
2 & $50 \%$ & Access w/ comp. & 2 & $33 \%$ & Access w/ comp. \\
3 & $25 \%$ & Access office & 3 & $33 \%$ & Access office \\
\hline
\end{tabular}

A rank order summary of the total population's

responses regarding the business office services that are available at the institutions is detailed in Table 7 .

Table 7

Business Office Services Population Summary

\begin{tabular}{ccl}
\hline RANK & $\%$ & ITEM \\
\hline 1 & $91 \%$ & Tuition installment plans \\
2 & $39 \%$ & Access to information via the computer \\
3 & $30 \%$ & Access to the office during evenings \\
\hline
\end{tabular}

The majority of public and private institutions reported that their business offices are not open during the evening and access is not available through the computer. However, tuition installment plans are available at 91\% of the institutions.

Counseling Services: Tables 8-10 
Responses to the counseling services category of the survey are reported in Tables 8 through 10. The mean percentages of the "yes" responses of the public and private institutions for items 12 through 18 of the survey are summarized in Table 8. A "yes" response indicated that the service is available at the institution.

Table 8

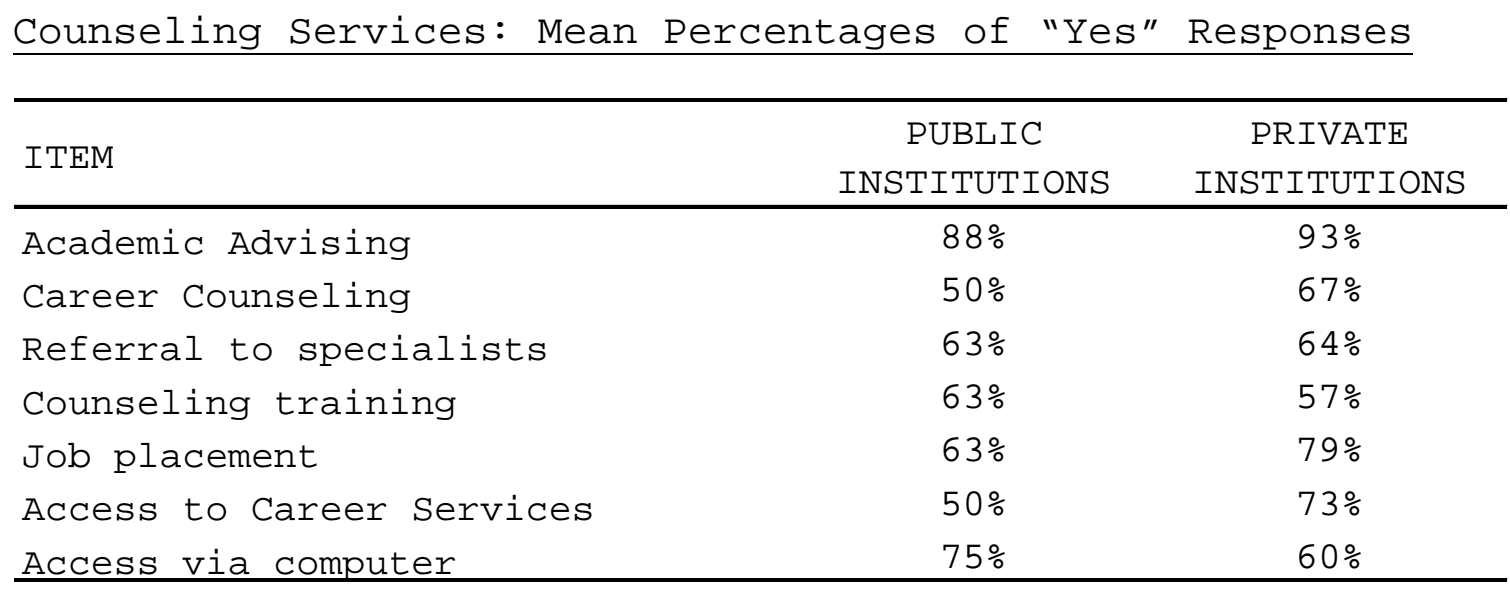

A rank order summary of the counseling services for the public and private institutions is provided in Table 9.

Table 9

Counseling Services: Rank Order Summary

\begin{tabular}{cclccl}
\hline & \multicolumn{2}{c}{ PUBLIC } & \multicolumn{3}{c}{ PRIVATE } \\
\hline RANK & $\%$ & ITEM & RANK & $\%$ & ITEM \\
\hline 1 & $88 \%$ & Academic advising & 1 & $93 \%$ & Academic advising \\
2 & $75 \%$ & Access computer & 2 & $79 \%$ & Job placement \\
3 & $63 \%$ & Referral special. & 3 & $73 \%$ & Access office \\
4 & $63 \%$ & Counseling train & 4 & $67 \%$ & Career counsel. \\
5 & $63 \%$ & Job Placement & 5 & $64 \%$ & Referral special. \\
6 & $50 \%$ & Career counsel & 6 & $60 \%$ & Access computer \\
7 & $50 \%$ & Access office & 7 & $57 \%$ & Counseling train. \\
\hline
\end{tabular}


Table 10 shows the rank order summary of the total population's responses regarding the counseling services that are available at the surveyed institutions.

Table 10

\section{Counseling Services Population Summary}

\begin{tabular}{ccl}
\hline RANK & $\%$ & ITEM \\
\hline 1 & $91 \%$ & Academic advising \\
2 & $73 \%$ & Job Placement after graduation \\
3 & $65 \%$ & Access to counseling information via computer \\
4 & $65 \%$ & Access to the career office during evenings \\
5 & $64 \%$ & Referral to specialists for adults \\
6 & $61 \%$ & Career counseling for adult students \\
7 & $59 \%$ & Counseling training on adult issues \\
\hline
\end{tabular}

The majority of public and private colleges reported that the all of the student services in the category of counseling are offered to the adult student population at their institutions. The service of academic advising had the greatest percentage of "yes" responses at $91.3 \%$. Financial Aid Services: Tables 11-13

Responses to the financial aid services category of the survey are reported in Tables 11 through 13. The mean percentages of the "yes" responses of the public and private institutions for items 19 through 24 of the survey are summarized in Table 11. A "yes" response indicated that the service is available at the institution.

Table 11

Financial Aid Services: Mean Percentages of "Yes" Responses 


\begin{tabular}{lcc}
\hline ITEM & $\begin{array}{c}\text { PUBLIC } \\
\text { INSTITUTIONS }\end{array}$ & $\begin{array}{c}\text { PRIVATE } \\
\text { INSTITUTIONS }\end{array}$ \\
\hline Publications & $25 \%$ & $60 \%$ \\
Assistance with forms & $88 \%$ & $80 \%$ \\
Loan programs & $25 \%$ & $20 \%$ \\
Scholarship programs & $13 \%$ & $43 \%$ \\
Access to office & $13 \%$ & $13 \%$ \\
Access via computer & $63 \%$ & $47 \%$ \\
\hline
\end{tabular}

Table 12 shows the rank order summary of the financial aid services for the public and private institutions.

Table 12

Financial Aid Services: Rank Order Summary

\begin{tabular}{cclccl}
\hline & \multicolumn{2}{c}{ PUBLIC } & \multicolumn{2}{c}{ PRIVATE } \\
\hline RANK & $\%$ & ITEM & RANK & $\%$ & ITEM \\
\hline 1 & $88 \%$ & Assistance & 1 & $80 \%$ & Assistance \\
2 & $63 \%$ & Access computer & 2 & $60 \%$ & Publications \\
3 & $25 \%$ & Publications & 3 & $47 \%$ & Access computer \\
4 & $25 \%$ & Loan Programs & 4 & $43 \%$ & Scholarships \\
5 & $13 \%$ & Scholarships & 5 & $20 \%$ & Loan program \\
6 & $13 \%$ & Access office & 6 & $13 \%$ & Access office \\
\hline
\end{tabular}

Table 13 presents the rank order summary of the total population's responses regarding the financial aid services that are available at the institutions.

Table 13

Financial Aid Services Population Summary

\begin{tabular}{ccl}
\hline RANK & $\%$ & ITEM \\
\hline 1 & $83 \%$ & Assistance for adults in completing forms \\
2 & $52 \%$ & Access to information via the computer \\
3 & $48 \%$ & Publications about financial services \\
4 & $32 \%$ & Scholarship programs for adult students \\
5 & $22 \%$ & Loan programs for adult students \\
6 & $13 \%$ & Access to the office during evenings \\
\hline
\end{tabular}


Eighty-three percent of public and private colleges reported that assistance for adult students in completing financial aid forms is provided and 52\% reported that their financial aid information can be accessed through the computer. The student services of publications developed for adult students, scholarship programs for adults, loan programs for adults, and access to the financial aid office during evening hours are not provided at the majority of public and private institutions.

Food Services: Tables 14-16

Responses to the food services category of the survey are reported in Tables 14 through 16. The mean percentages of the "yes" responses of the public and private institutions for items 25 through 28 of the survey are summarized in Table 14. A "yes" response indicated that the service is available at the institution.

Table 14

Food Services: Mean Percentages of "Yes" Responses

\begin{tabular}{lcc}
\hline ITEM & $\begin{array}{c}\text { PUBLIC } \\
\text { INSTITUTIONS }\end{array}$ & $\begin{array}{c}\text { PRIVATE } \\
\text { INSTITUTIONS }\end{array}$ \\
\hline Vending services & $100 \%$ & $87 \%$ \\
Snack bar & $100 \%$ & $73 \%$ \\
Full service cafeteria & $75 \%$ & $27 \%$ \\
Charge cards & $88 \%$ & $33 \%$ \\
\hline
\end{tabular}

A rank order summary of the food services offered at the public and private institutions is reported in Table 15. Table 15 
Food Services: Rank Order Summary

\begin{tabular}{cclccl}
\hline & \multicolumn{2}{c|}{ PUBLIC } & \multicolumn{3}{c}{ PRIVATE } \\
\hline RANK & $\%$ & ITEM & RANK & $\frac{\circ}{\circ}$ & ITEM \\
\hline 1 & $100 \%$ & Vending & 1 & $87 \%$ & Vending \\
2 & $100 \%$ & Snack bar & 2 & $73 \%$ & Snack bar \\
3 & $88 \%$ & Charge cards & 3 & $33 \%$ & Charge cards \\
4 & $75 \%$ & Cafeteria & 4 & $27 \%$ & Cafeteria \\
\hline
\end{tabular}

Table 16 depicts the rank order summary of the total population's responses regarding the food services that are provided at the institutions.

Table 16

Food Services Population Summary

\begin{tabular}{ccl}
\hline RANK & $\%$ & ITEM \\
\hline 1 & $91 \%$ & Vending area open evenings and weekends \\
2 & $83 \%$ & Snack bar open evenings and weekends \\
3 & $52 \%$ & Charge cards available for convenience \\
4 & $44 \%$ & Full service cafeteria open evenings \\
\hline
\end{tabular}

The majority of public and private colleges reported that the food services provided at the institutions include vending areas and snack bars open during evening and weekend hours. Fifty-two percent of the institutions offered to adult students the option of using charge cards to pay for food at their facilities. The only service in this category that was not offered by the majority of institutions was the provision of full-service cafeterias open during evening and weekend hours. 
Orientation Services: Tables 17-19

Responses to the orientation services category of the survey are reported in Tables 17 through 19. The mean percentages of the "yes" responses of the public and private institutions for items 29 through 31 of the survey are summarized in Table 17. A "yes" response indicated that the service is available at the institution.

Table 17

Orientation Services: Mean Percentages of "Yes" Responses

\begin{tabular}{lcc}
\hline ITEM & $\begin{array}{c}\text { PUBLIC } \\
\text { INSTITUTIONS }\end{array}$ & $\begin{array}{c}\text { PRIVATE } \\
\text { INSTITUTIONS }\end{array}$ \\
\hline Continuous Orientation & $13 \%$ & $33 \%$ \\
General Orientation & $25 \%$ & $67 \%$ \\
Peer Advising Program & $13 \%$ & $20 \%$ \\
\hline
\end{tabular}

A rank order summary of the orientation services specifically directed toward adult students provided at the public and private institutions is shown in Table 18.

Table 18

Orientation Services: Rank Order Summary

\begin{tabular}{cclccl}
\hline \multicolumn{2}{c}{ PUBLIC } & \multicolumn{3}{c}{ PRIVATE } \\
\hline RANK & $\circ$ & ITEM & RANK & $\div$ & ITEM \\
\hline 1 & $25 \%$ & General Orien. & 1 & $67 \%$ & General Orien. \\
2 & $13 \%$ & Continuous Orien & 2 & $33 \%$ & Continuous Orien \\
3 & $13 \%$ & Peer Advising & 3 & $20 \%$ & Peer Advising \\
\hline
\end{tabular}

Table 19 describes the rank order summary of the total population's responses regarding that orientation services for adult students that are offered at the institutions. 
Table 19

Orientation Services Population Summary

\begin{tabular}{ccl}
\hline RANK & $\%$ & ITEM \\
\hline 1 & $52 \%$ & General Orientation program for adults \\
2 & $26 \%$ & Continuous orientation program for adults \\
3 & $17 \%$ & Peer advising program for adults \\
\hline
\end{tabular}

Half of the public and private institutions offer

general orientation programs designed for adult students.

Less than one third of the institutions provide continuous orientation sessions for adult students or peer advising programs targeted for the adult student population. College Personnel Services: Tables 20-22

Responses to the college personnel services category of the survey are reported in Tables 20 through 22. The mean percentages of the "yes" responses of the public and private institutions for items 32 through 34 of the survey are summarized in Table 20. A "yes" response indicated that the service is available at the institution.

Table 20

College Personnel Services: Mean Percentages of "Yes" Responses

\begin{tabular}{lcc}
\hline ITEM & PUBLIC & PRIVATE \\
& INSTITUTIONS & INSTITUTIONS \\
\hline Administrators with experience & $50 \%$ & $100 \%$ \\
Faculty with experience & $63 \%$ & $93 \%$ \\
Administrators are trained & $50 \%$ & $73 \%$ \\
\hline
\end{tabular}


Table 21 presents the rank order summary of the college personnel services for adult students at the public and private institutions.

Table 21

College Personnel Services: Rank Order Summary

\begin{tabular}{cclccl}
\hline \multicolumn{2}{c}{ PUBLIC } & \multicolumn{3}{c}{ PRIVATE } \\
\hline RANK & $\circ$ & ITEM & RANK & $\%$ & ITEM \\
\hline 1 & $63 \%$ & Faculty exper. & 1 & $100 \%$ & Staff experience \\
2 & $50 \%$ & Staff experience & 2 & $93 \%$ & Faculty exper. \\
3 & $50 \%$ & Staff trained & 3 & $73 \%$ & Staff trained \\
\hline
\end{tabular}

A rank order summary of the total population's

responses regarding the college personnel services that are available at the institutions is shown below.

Table 22

College Personnel Services Population Summary

\begin{tabular}{ccl}
\hline RANK & $\%$ & ITEM \\
\hline 1 & $83 \%$ & Faculty with experience working with adults \\
2 & $83 \%$ & Staff with experience working with adults \\
3 & $65 \%$ & Staff trained in adult development \\
\hline
\end{tabular}

Eighty-three percent of the public and private institutions have faculty and staff who have experience working with adult students and 65\% have staff who are trained in adult student development and learning characteristics.

Registration Services: Tables 23-25

Responses to the registration services category of the survey are reported in Tables 23 through 25. The mean 
percentages of the "yes" responses of the public and private institutions for items 35 through 41 of the survey are summarized in Table 23. A "yes" response indicated that the service is available at the institution.

Table 23

Registration Services: Mean Percentages of "Yes" Responses

\begin{tabular}{lcc}
\hline ITEM & $\begin{array}{c}\text { PUBLIC } \\
\text { INSTITUTIONS }\end{array}$ & $\begin{array}{c}\text { PRIVATE } \\
\text { INSTITUTIONS }\end{array}$ \\
\hline Registration assistance & $63 \%$ & $93 \%$ \\
Pre-registration & $88 \%$ & $93 \%$ \\
Registration by mail & $50 \%$ & $60 \%$ \\
Registration by phone & $63 \%$ & $27 \%$ \\
Registration by e-mail & $29 \%$ & $7 \%$ \\
Access to office & $38 \%$ & $13 \%$ \\
Access via computer & $100 \%$ & $21 \%$ \\
\hline
\end{tabular}

Table 24 depicts the rank order summary of the registration services for the public and private institutions.

Table 24

Registration Services: Rank Order Summary

\begin{tabular}{cclccl}
\hline & \multicolumn{2}{c}{ PUBLIC } & \multicolumn{3}{c}{ PRIVATE } \\
\hline RANK & $\%$ & ITEM & RANK & $\%$ & ITEM \\
\hline 1 & $100 \%$ & Access computer & 1 & $93 \%$ & Pre-registration \\
2 & $88 \%$ & Pre-registration & 2 & $93 \%$ & Assistance \\
3 & $63 \%$ & Assistance & 3 & $60 \%$ & Reg. by mail \\
4 & $63 \%$ & Reg. by phone & 4 & $27 \%$ & Reg. by phone \\
5 & $50 \%$ & Reg. by mail & 5 & $21 \%$ & Access computer \\
6 & $38 \%$ & Access office & 6 & $13 \%$ & Access office \\
7 & $29 \%$ & Reg. by e-mail & 7 & $7 \%$ & Reg. by e-mail \\
\hline
\end{tabular}

Table 25 shows the rank order summary of the total population's responses regarding the registration services that are available at the institutions. 
Table 25

Registration Services Population Summary

\begin{tabular}{ccl}
\hline RANK & $\%$ & ITEM \\
\hline 1 & $91 \%$ & Pre-registration available \\
2 & $82 \%$ & Registration assistance for adults \\
3 & $57 \%$ & Registration by mail \\
4 & $50 \%$ & Access to information via the computer \\
5 & $39 \%$ & Registration by phone \\
6 & $22 \%$ & Access to the office during evenings \\
7 & $14 \%$ & Registration by e-mail \\
\hline
\end{tabular}

The majority of public and private colleges reported that their institutions provide pre-registration for their adult students as well as assistance with registration. Roughly half of the institutions offer access to the registration office via the computer and provide the service of registering for classes by mail. Student Activities Services: Tables 26-28

Responses to the student activities services category of the survey are reported in Tables 26 through 28 . The mean percentages of the "yes" responses of the public and private institutions for items 42 through 46 of the survey are summarized in Table 26. A "yes" response indicated that the service is available at the institution.

Table 26 
Student Activities Services: Mean Percentages of "Yes"

Responses

\begin{tabular}{lcc}
\hline ITEM & $\begin{array}{c}\text { PUBLIC } \\
\text { INSTITUTIONS }\end{array}$ & $\begin{array}{c}\text { PRIVATE } \\
\text { INSTITUTIONS }\end{array}$ \\
\hline Student organization(s) & $50 \%$ & $64 \%$ \\
Rec. facilities in evening & $75 \%$ & $86 \%$ \\
Rec. facilities for family & $63 \%$ & $73 \%$ \\
Student governance & $75 \%$ & $64 \%$ \\
Cultural activities & $100 \%$ & $93 \%$ \\
\hline
\end{tabular}

The rank ordered summary of the student activities

services for the public and private institutions is provided here.

Table 27

Student Activities Services: Rank Order Summary

\begin{tabular}{cclccl}
\hline & \multicolumn{2}{c}{ PUBLIC } & \multicolumn{3}{c}{ PRIVATE } \\
\hline RANK & $\%$ & ITEM & RANK & $\%$ & ITEM \\
\hline 1 & $100 \%$ & Cultural & 1 & $93 \%$ & Cultural \\
2 & $75 \%$ & Student govern. & 2 & $86 \%$ & Rec facilities \\
3 & $75 \%$ & Rec facilities & 3 & $73 \%$ & Rec for family \\
4 & $63 \%$ & Rec for family & 4 & $64 \%$ & Student govern. \\
5 & $50 \%$ & Student org. & 5 & $64 \%$ & Student org. \\
\hline
\end{tabular}

The total population's responses regarding the student activities services that are available at the institutions are presented in Table 28 .

Table 28

$\underline{\text { Student Activities Services Population Summary }}$ 


\begin{tabular}{ccl}
\hline RANK & $\frac{\circ}{\circ}$ & ITEM \\
\hline 1 & $96 \%$ & Cultural activities and programs \\
2 & $82 \%$ & Recreational facilities available evenings \\
3 & $70 \%$ & Recreational facilities provided for family \\
4 & $68 \%$ & Student governance opportunities for adults \\
5 & $59 \%$ & Student organization $(s)$ for adults \\
\hline
\end{tabular}

The majority of public and private colleges reported that they provide all five of the student activities listed. A total of $95.7 \%$ of the institutions offered cultural activities.

Educational Support Services: Tables 29-31

Responses to the educational support services category of the survey are reported in Tables 29 through 31 . The mean percentages of the "yes" responses of the public and private institutions for items 47 through 57 of the survey are summarized in Table 29. A "yes" response indicated that the service is available at the institution.

Table 29

Educational Support Services: Mean Percentages of "Yes" $\underline{\text { Responses }}$ 


\begin{tabular}{lcc}
\hline ITEM & $\begin{array}{c}\text { PUBLIC } \\
\text { INSTITUTIONS }\end{array}$ & $\begin{array}{c}\text { PRIVATE } \\
\text { INSTITUTIONS }\end{array}$ \\
\hline Disabled student services & $100 \%$ & $93 \%$ \\
Tutoring & $75 \%$ & $93 \%$ \\
Study skills workshops & $100 \%$ & $93 \%$ \\
Library use workshops & $100 \%$ & $100 \%$ \\
Library facility open & $100 \%$ & $87 \%$ \\
Time management workshops & $100 \%$ & $73 \%$ \\
Student lounge & $100 \%$ & $87 \%$ \\
Study areas & $86 \%$ & $87 \%$ \\
Computer lab & $100 \%$ & $100 \%$ \\
Security lockers & $57 \%$ & $47 \%$ \\
Centralized locations & $63 \%$ & $47 \%$ \\
\hline
\end{tabular}

Table 30 depicts the rank order summary of the educational support services provided at the public and private institutions.

Table 30

Educational Support Services: Rank Order Summary

\begin{tabular}{cclccl}
\hline & \multicolumn{2}{c}{ PUBLIC } & \multicolumn{3}{c}{ PRIVATE } \\
\hline RANK & $\%$ & ITEM & RANK & $\%$ & ITEM \\
\hline 1 & $100 \%$ & Disabled & 1 & $100 \%$ & Library workshop \\
2 & $100 \%$ & Study skills & 2 & $100 \%$ & Computer lab \\
3 & $100 \%$ & Library workshop & 3 & $93 \%$ & Disabled \\
4 & $100 \%$ & Library open & 4 & $93 \%$ & Tutoring \\
5 & $100 \%$ & Time management & 5 & $93 \%$ & Study skills \\
6 & $100 \%$ & Student lounge & 6 & $87 \%$ & Library open \\
7 & $100 \%$ & Computer lab & 7 & $87 \%$ & Student lounge \\
8 & $86 \%$ & Study areas & 8 & $87 \%$ & Study areas \\
9 & $75 \%$ & Tutoring & 9 & $73 \%$ & Time management \\
10 & $63 \%$ & Central location & 10 & $47 \%$ & Central location \\
11 & $57 \%$ & Security lockers & 11 & $47 \%$ & Security lockers \\
\hline
\end{tabular}

A rank order summary of the total population's

responses regarding the educational support services that are available at the institutions follows.

Table 31 
Educational Support Services Population Summary

\begin{tabular}{ccl}
\hline RANK & $\frac{\circ}{\circ}$ & ITEM \\
\hline 1 & $100 \%$ & Library use workshop \\
1 & $100 \%$ & Computer lab open with adequate computers \\
3 & $96 \%$ & Disabled student services \\
3 & $96 \%$ & Study skills workshops \\
5 & $91 \%$ & Library open at hours to accommodate adults \\
6 & $91 \%$ & Student lounge areas available \\
7 & $87 \%$ & Developmental student services/Tutoring \\
8 & $86 \%$ & Study areas \\
9 & $83 \%$ & Time management workshops \\
10 & $52 \%$ & Classes conducted at centralized locations \\
11 & $50 \%$ & Security lockers available for storage \\
\hline
\end{tabular}

One hundred percent of the public and private institutions reported that they provide library use workshops and computer labs for student use. Over $80 \%$ percent of institutions also offer disabled student services, study skills workshops, a library open during evenings and weekends, student lounges, tutoring, study areas, and time management workshops. Only half of the institutions offer centralized class locations and security lockers. 
Residential Life Services: Tables 32-34

Responses to the residential life services category of the survey are reported in Tables 32 through 34 . The mean percentages of the "yes" responses of the public and private institutions for items 58 and 59 of the survey are summarized in Table 32. A "yes" response indicated that the service is available at the institution.

Table 32

Residential Life Services: Mean Percentages of "Yes" Responses

\begin{tabular}{lcc}
\hline ITEM & PUBLIC & PRIVATE \\
& INSTITUTIONS & INSTITUTIONS \\
\hline Overnight/Weekend housing & $25 \%$ & $40 \%$ \\
Residential staff trained & $50 \%$ & $33 \%$ \\
\hline
\end{tabular}

Table 33 presents the rank order summary of the residential life services designed for the adult student population at the public and private institutions.

Table 33

Residential Life Services: Rank Order Summary

\begin{tabular}{cclccl}
\hline & PUBLIC & \multicolumn{3}{c}{ PRIVATE } \\
\hline RANK & $\%$ & ITEM & RANK & $\%$ & ITEM \\
\hline 1 & $50 \%$ & Res staff trained & 1 & $40 \%$ & Weekend housing \\
2 & $25 \%$ & Weekend housing & 2 & $33 \%$ & Res staff trained \\
\hline
\end{tabular}

The total population's responses regarding the residential life services that are available at the institutions is presented in rank order summary in Table 34. Table 34

Residential Life Services Population Summary 


\begin{tabular}{ccl}
\hline RANK & $\circ$ & ITEM \\
\hline 1 & $39 \%$ & Residential staff trained on adult issues \\
2 & $35 \%$ & Overnight and/or weekend housing \\
\hline
\end{tabular}

The majority of public and private colleges reported that the residential life services designed for adult students are not available at their institutions. Only 39\% of the colleges have residential staff trained to work with adult students and 35\% provide weekend and/or evening housing

Parking and Transportation Services: Tables 35-37

Responses to the parking and transportation services category of the survey are reported in Tables 35 through 37 . The mean percentages of the "yes" responses of the public and private institutions for items 60 through 62 of the survey are summarized in Table 35. A "yes" response indicated that the service is available at the institution. 
Table 35

$\underline{\text { Parking and Transportation Services: Mean Percentages of }}$ "Yes" Responses

\begin{tabular}{lcc}
\hline ITEM & PUBLIC & PRIVATE \\
& INSTITUTIONS & INSTITUTIONS \\
\hline Bus service & $63 \%$ & $29 \%$ \\
Adequate/well-lighted parking & $87 \%$ & $100 \%$ \\
Security personnel & $100 \%$ & $87 \%$ \\
\hline
\end{tabular}

Table 36 shows the rank ordered summary of the parking and transportation services for the public and private institutions.

Table 36

$\underline{\text { Parking and Transportation Services: Rank Order Summary }}$

\begin{tabular}{cclccl}
\hline \multicolumn{2}{c}{ PUBLIC } & \multicolumn{3}{c}{ PRIVATE } \\
\hline RANK & $\circ$ & ITEM & RANK & $\%$ & ITEM \\
\hline 1 & $100 \%$ & Security & 1 & $100 \%$ & Adequate parking \\
2 & $87 \%$ & Adequate parking & 2 & $87 \%$ & Security \\
3 & $63 \%$ & Bus service & 3 & $29 \%$ & Bus services \\
\hline
\end{tabular}

The total population's responses regarding the parking and transportation services that are available at the institutions is presented in rank order summary in Table 37. Table 37

Parking and Transportation Services Population Summary

\begin{tabular}{ccl}
\hline RANK & $\%$ & ITEM \\
\hline 1 & $94 \%$ & Adequate and well-lighted parking \\
2 & $94 \%$ & Security personnel on duty at all times \\
3 & $41 \%$ & Bus service to buildings from parking \\
\hline
\end{tabular}

Over 90\% of public and private colleges reported that the parking and transportation services at their 
institutions provide adequate parking and security personnel who are on duty at all times.

Miscellaneous Services: Tables 38-40

Responses to the miscellaneous services category of the survey are reported in Tables 38 through 40 . The mean

percentages of the "yes" responses of the public and private institutions for items 63 through 65 of the survey are summarized in Table 38. A "yes" response indicated that the service is available at the institution.

Table 38

Miscellaneous Services: Mean Percentages of "Yes" Responses

\begin{tabular}{lcc}
\hline ITEM & PUBLIC & PRIVATE \\
& INSTITUTIONS & INSTITUTIONS \\
\hline Student health services & $100 \%$ & $40 \%$ \\
Child care services & $38 \%$ & $20 \%$ \\
Child care referral services & $50 \%$ & $20 \%$ \\
\hline
\end{tabular}

A rank order summary of the miscellaneous services for adult students at the public and private institutions is provided in Table 39.

Table 39

Miscellaneous Services: Rank Order Summary 


\begin{tabular}{cclccl}
\hline \multicolumn{2}{c|}{ PUBLIC } & \multicolumn{3}{c}{ PRIVATE } \\
\hline RANK & $\circ$ & ITEM & RANK & $\%$ & ITEM \\
\hline 1 & $100 \%$ & Student health & 1 & $40 \%$ & Student health \\
2 & $50 \%$ & Child referral & 2 & $20 \%$ & Child referral \\
3 & $38 \%$ & Child care & 3 & $20 \%$ & Child care \\
\hline
\end{tabular}

Table 40 depicts the rank order summary of the total population's responses regarding the miscellaneous services directed toward the adult student population that are available at the institutions.

Table 40

Miscellaneous Services Population Summary

\begin{tabular}{ccl}
\hline RANK & $\frac{\circ}{\circ}$ & ITEM \\
\hline 1 & $61 \%$ & Student health services \\
2 & $30 \%$ & Child care referral services \\
3 & $26 \%$ & Child care services \\
\hline
\end{tabular}

The majority of public and private colleges reported that student health services are available for their adult student population at their institutions. Only one-third of the institutions provide child care and child care referral services. 


\section{Success of the student Services}

The data for research question \#2 determined the success in attracting adult students to the available student services identified in question \#1: which student services offered to adult students are successful and which are unsuccessful in attracting adult students.

The population's responses are reported as percentages and are summarized in Tables 41 through 79. Respondents rated each student service using the following Likert scale: (1) very successful, (2) successful, and (3) not successful. Three tables are provided for each category of student services listed in the survey. The first table presents the data from the respondents at the public institutions. The second table shows the summarized responses from the administrators at the private institutions. The final table depicts the summarized data for the total population. Admissions Services: Tables $41-43$

The population was asked to rate the success of the eight admissions services identified in the survey. The responses for each item at the public institutions are presented in Table 41 .

Table 41

Admissions Services: Public Institutions 


\begin{tabular}{|c|c|c|c|}
\hline & 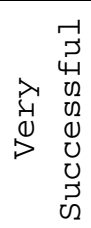 & $\begin{array}{l}7 \\
3 \\
4 \\
01 \\
02 \\
02 \\
0 \\
0 \\
0 \\
0 \\
2 \\
02\end{array}$ & 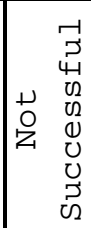 \\
\hline $\begin{array}{l}\text { Recruitment materials directed specifically to adult } \\
\text { students }\end{array}$ & $33 \%$ & $64 \%$ & $0 \%$ \\
\hline Direct recruitment of adult students & $0 \%$ & $100 \%$ & $0 \%$ \\
\hline $\begin{array}{l}\text { Personnel recruitment visits with prospective adult } \\
\text { students }\end{array}$ & $20 \%$ & $60 \%$ & $20 \%$ \\
\hline Special admissions criteria for adult students & $33 \%$ & $34 \%$ & $33 \%$ \\
\hline $\begin{array}{l}\text { Provision of advanced academic standing for work } \\
\text { experience or training }\end{array}$ & $25 \%$ & $75 \%$ & $0 \%$ \\
\hline Ability to apply for a part-time degree program & $60 \%$ & $40 \%$ & $0 \%$ \\
\hline Access to the Admissions office during evenings & $33 \%$ & $64 \%$ & $0 \%$ \\
\hline $\begin{array}{l}\text { Access to information via computer with the Admissions } \\
\text { office }\end{array}$ & $43 \%$ & $57 \%$ & $0 \%$ \\
\hline
\end{tabular}

Table 42 shows the responses for the items in the category of admissions services for the private institutions.

Table 42

Admission Services: Private Institutions 


\begin{tabular}{|c|c|c|c|}
\hline & 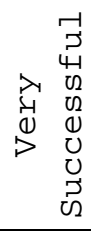 & $\begin{array}{l}-1 \\
3 \\
4 \\
02 \\
02 \\
0 \\
0 \\
0 \\
0 \\
I \\
02\end{array}$ & 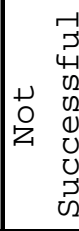 \\
\hline $\begin{array}{l}\text { Recruitment materials directed specifically to adult } \\
\text { students }\end{array}$ & $36 \%$ & $64 \%$ & $0 \%$ \\
\hline Direct recruitment of adult students & $50 \%$ & $50 \%$ & $0 \%$ \\
\hline $\begin{array}{l}\text { Personnel recruitment visits with prospective adult } \\
\text { students }\end{array}$ & $57 \%$ & $29 \%$ & $14 \%$ \\
\hline Special admissions criteria for adult students & $43 \%$ & $57 \%$ & $0 \%$ \\
\hline $\begin{array}{l}\text { Provision of advanced academic standing for work } \\
\text { experience or training }\end{array}$ & $70 \%$ & $20 \%$ & $10 \%$ \\
\hline Ability to apply for a part-time degree program & $80 \%$ & $10 \%$ & $10 \%$ \\
\hline Access to the Admissions office during evenings & $63 \%$ & $25 \%$ & $12 \%$ \\
\hline $\begin{array}{l}\text { Access to information via computer with the Admissions } \\
\text { office }\end{array}$ & $15 \%$ & $70 \%$ & $15 \%$ \\
\hline
\end{tabular}

The summarized responses for the admission services for the population regarding the success of the student services in attracting adult students are depicted in Table 43 .

Table 43

Admissions Services: Total Population 


\begin{tabular}{|c|c|c|c|}
\hline & 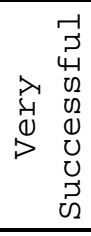 & $\begin{array}{l}71 \\
3 \\
4 \\
02 \\
02 \\
1 \\
0 \\
0 \\
0 \\
3 \\
0 \\
0\end{array}$ & 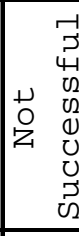 \\
\hline $\begin{array}{l}\text { Recruitment materials directed specifically to adult } \\
\text { students }\end{array}$ & $36 \%$ & $64 \%$ & $0 \%$ \\
\hline Direct recruitment of adult students & $36 \%$ & $64 \%$ & $0 \%$ \\
\hline $\begin{array}{l}\text { Personnel recruitment visits with prospective adult } \\
\text { students }\end{array}$ & $42 \%$ & $42 \%$ & $16 \%$ \\
\hline Special admissions criteria for adult students & $40 \%$ & $50 \%$ & $10 \%$ \\
\hline $\begin{array}{l}\text { Provision of advanced academic standing for work } \\
\text { experience or training }\end{array}$ & $57 \%$ & $36 \%$ & $7 \%$ \\
\hline Ability to apply for a part-time degree program & $73 \%$ & $20 \%$ & $7 \%$ \\
\hline Access to the Admissions office during evenings & $55 \%$ & $36 \%$ & $9 \%$ \\
\hline $\begin{array}{l}\text { Access to information via computer with the Admissions } \\
\text { office }\end{array}$ & $25 \%$ & $65 \%$ & $10 \%$ \\
\hline
\end{tabular}

Public institutions rated all admissions services as "successful" and "very successful" in attracting adult students. However, the service of special admissions criteria for adult students had a "not successful" percentage of $33 \%$

Private institutions rated half of the eight admissions services as "very successful" and half as "successful" in attracting adult students. The ratings for "not successful" were very low.

The population rated four admissions services as "successful" and three services as "very successful" with the most successful admission service being the ability to apply for a part-time degree program.

Business Services: Tables $44-46$

The population was asked to rate the success in attracting adult students to the three business services 
identified in the survey. The responses for each item at the public institutions are detailed in Table 44.

Table 44

Business Services: Public Institutions

\begin{tabular}{|c|c|c|c|}
\hline & 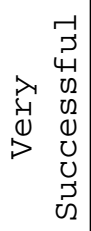 & $\begin{array}{l}-1 \\
3 \\
4 \\
02 \\
02 \\
0 \\
0 \\
0 \\
0 \\
5 \\
0\end{array}$ & 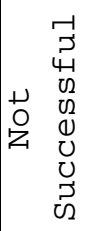 \\
\hline Tuition installment plans & $29 \div$ & $71 \%$ & $0 \%$ \\
\hline Access to the Business office during evenings & $0 \%$ & $50 \%$ & $50 \%$ \\
\hline Access to information via computer with the Business & & & \\
\hline office & $25 \div$ & $75 \%$ & $0 \%$ \\
\hline
\end{tabular}

Table 45 describes the responses for items in the category of business services as listed in the survey for the private institutions.

Table 45

Business Services: Private Institutions

\begin{tabular}{|c|c|c|c|}
\hline & 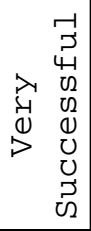 & $\begin{array}{l}-1 \\
5 \\
3 \\
02 \\
02 \\
0 \\
0 \\
0 \\
5 \\
02 \\
0\end{array}$ & 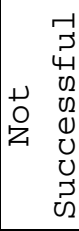 \\
\hline Tuition installment plans & $43 \%$ & $50 \%$ & $7 \%$ \\
\hline Access to the Business office during evenings & $20 \%$ & $80 \%$ & $0 \div$ \\
\hline $\begin{array}{l}\text { Access to information via computer with the Business } \\
\text { office }\end{array}$ & $40 \%$ & $40 \%$ & $20 \%$ \\
\hline
\end{tabular}


The summary of the population's responses for the category of business services is reported in Table 46. Table 46

Business Services: Total Population

\begin{tabular}{|c|c|c|c|}
\hline & 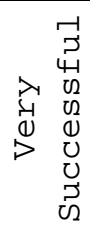 & $\begin{array}{l}1 \\
3 \\
3 \\
01 \\
02 \\
1 \\
0 \\
0 \\
0 \\
5 \\
02\end{array}$ & 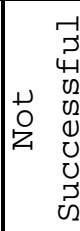 \\
\hline Tuition installment plans & $38 \%$ & $57 \div$ & $5 \%$ \\
\hline Access to the Business office during evenings & $14 \%$ & $72 \%$ & $14 \%$ \\
\hline $\begin{array}{l}\text { Access to information via computer with the Business } \\
\text { office }\end{array}$ & $33 \%$ & $56 \%$ & $11 \%$ \\
\hline
\end{tabular}

Public institutions rated the services of tuition installment plans and access to information via the computer as "successful" in attracting adult students. The service of access to the business office during the evenings was given equal percentages between the ratings of "successful" and "not successful" in attracting adult students. Private institutions rated all business services as "successful" in attracting adult students. The response rate for the service of access to information via the computer was tied with "very successful". The population rated all three business services as "successful" in attracting adult students. Counseling Services: Tables 47-50

The population was asked to rate the success of the seven counseling services identified in the survey. The 
responses for each item at the public institutions are presented in Table 47.

Table 47

Counseling Services: Public Institutions

\begin{tabular}{|c|c|c|c|}
\hline & 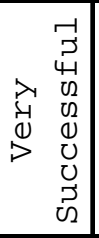 & $\begin{array}{l}71 \\
5 \\
4 \\
0 \\
02 \\
02 \\
0 \\
0 \\
0 \\
0 \\
0 \\
0 \\
\end{array}$ & 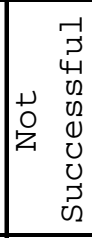 \\
\hline Academic Advising & $0 \%$ & $100 \%$ & $0 \%$ \\
\hline $\begin{array}{l}\text { Career Counseling and Development specifically for adult } \\
\text { students }\end{array}$ & $0 \%$ & $100 \%$ & $0 \%$ \\
\hline $\begin{array}{l}\text { Referral to specialists for adults needing special } \\
\text { services }\end{array}$ & $20 \%$ & $80 \%$ & $0 \%$ \\
\hline Counseling with training in adult student issues & $0 \%$ & $100 \%$ & $0 \%$ \\
\hline Post graduation job placement services & $0 \%$ & $100 \%$ & $0 \%$ \\
\hline Access to career counseling services during evenings & $0 \%$ & $100 \%$ & $0 \%$ \\
\hline $\begin{array}{l}\text { Access to information via the computer for the } \\
\text { counseling services }\end{array}$ & $0 \%$ & $100 \div$ & $0 \div$ \\
\hline
\end{tabular}

Table 48 presents the responses for items in the category of counseling services as listed in the survey for the private institutions.

Table 48 
Counseling Services: Private Institutions

\begin{tabular}{|c|c|c|c|}
\hline & 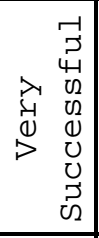 & $\begin{array}{l}-1 \\
3 \\
3 \\
01 \\
02 \\
02 \\
0 \\
0 \\
0 \\
5 \\
0 \\
2 \\
\end{array}$ & 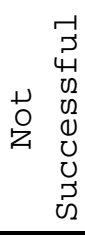 \\
\hline Academic Advising & $50 \%$ & $43 \%$ & $7 \%$ \\
\hline $\begin{array}{l}\text { Career Counseling and Development specifically for adult } \\
\text { students }\end{array}$ & $20 \%$ & $70 \%$ & $10 \%$ \\
\hline $\begin{array}{l}\text { Referral to specialists for adults needing special } \\
\text { services }\end{array}$ & $44 \%$ & $44 \%$ & $12 \%$ \\
\hline Counseling with training in adult student issues & $50 \%$ & $50 \%$ & $0 \%$ \\
\hline Post graduation job placement services & $18 \%$ & $55 \%$ & $27 \%$ \\
\hline $\begin{array}{l}\text { Access to career counseling services during evenings } \\
\text { Access to information via the computer for the }\end{array}$ & $27 \%$ & $64 \%$ & $9 \%$ \\
\hline counseling services & $11 \%$ & $89 \%$ & $0 \%$ \\
\hline
\end{tabular}

The summary of the population's responses for the

category of counseling services is portrayed in Table 49.

Table 49

Counseling Services: Total Population 


\begin{tabular}{|c|c|c|c|}
\hline & 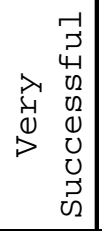 & $\begin{array}{l}-1 \\
2 \\
41 \\
02 \\
02 \\
0 \\
0 \\
0 \\
0 \\
5 \\
02\end{array}$ & 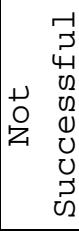 \\
\hline Academic Advising & $35 \%$ & $60 \%$ & $5 \%$ \\
\hline $\begin{array}{l}\text { Career Counseling and Development specifically for adult } \\
\text { students }\end{array}$ & $14 \%$ & $79 \%$ & $7 \%$ \\
\hline $\begin{array}{l}\text { Referral to specialists for adults needing special } \\
\text { services }\end{array}$ & $36 \%$ & $57 \%$ & $7 \%$ \\
\hline Counseling with training in adult student issues & $29 \div$ & $71 \%$ & $0 \div$ \\
\hline Post graduation job placement services & $13 \%$ & $69 \%$ & $18 \%$ \\
\hline Access to career counseling services during evenings & $20 \%$ & $73 \%$ & $7 \%$ \\
\hline $\begin{array}{l}\text { Access to information via the computer for the counseling } \\
\text { services }\end{array}$ & $7 \%$ & $93 \%$ & $0 \%$ \\
\hline
\end{tabular}

Public institutions rated all of the seven counseling services as "successful" in attracting adult students. No services had a rating of "not successful" for their adult student population.

Private institutions were more varied in their responses. Two counseling services had equal percentages for "successful" and "very successful" for the services of referral to specialists and job placement after graduation. All other services were rated as "successful" in attracting adult students.

The population rated all seven counseling services as "successful" in attracting adult students. Access to information via the computer had the highest percentage at $93 \div$

Financial Aid Services: Tables 50-52

The population was asked to rate the success in attracting adult students to the six financial aid services 
identified in the survey. The responses for each item for the public institutions are shown in Table 50.

Table 50

Financial Aid Services: Public Institutions

\begin{tabular}{|c|c|c|c|}
\hline & 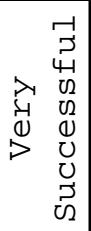 & $\begin{array}{l}-1 \\
53 \\
41 \\
02 \\
02 \\
01 \\
0 \\
0 \\
5 \\
5 \\
0\end{array}$ & 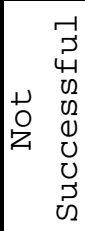 \\
\hline $\begin{array}{l}\text { Publications that outline financial aid programs and } \\
\text { services for adult students }\end{array}$ & $0 \%$ & $100 \%$ & $0 \%$ \\
\hline $\begin{array}{l}\text { Assistance for adult students in completing financial aid } \\
\text { forms }\end{array}$ & $17 \%$ & $83 \%$ & $0 \%$ \\
\hline Loan programs designed specifically for adult students & $50 \div$ & $50 \%$ & $0 \%$ \\
\hline $\begin{array}{l}\text { Scholarship programs designed specifically for adult } \\
\text { students }\end{array}$ & $0 \%$ & $100 \%$ & $0 \%$ \\
\hline Access to the Financial Aid office during evenings & $0 \%$ & $100 \%$ & $0 \%$ \\
\hline $\begin{array}{l}\text { Access to information via computer with the Financial Aid } \\
\text { office }\end{array}$ & $20 \%$ & $60 \%$ & $20 \%$ \\
\hline
\end{tabular}

Table 51 details the responses for the items in the category of financial aid services for the private institutions.

Table 51

Financial Aid Services: Private Institutions 


\begin{tabular}{|c|c|c|c|}
\hline & 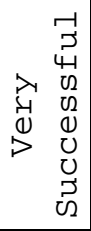 & $\begin{array}{l}-1 \\
3 \\
41 \\
02 \\
02 \\
0 \\
0 \\
0 \\
5 \\
5 \\
0\end{array}$ & 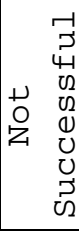 \\
\hline $\begin{array}{l}\text { Publications that outline financial aid programs and } \\
\text { services for adult students }\end{array}$ & 33\% & $67 \%$ & $0 \%$ \\
\hline $\begin{array}{l}\text { Assistance for adult students in completing financial aid } \\
\text { forms }\end{array}$ & $25 \%$ & $66 \%$ & $9 \%$ \\
\hline Loan programs designed specifically for adult students & $33 \%$ & $64 \%$ & $0 \%$ \\
\hline $\begin{array}{l}\text { Scholarship programs designed specifically for adult } \\
\text { students }\end{array}$ & $50 \%$ & $50 \%$ & $0 \%$ \\
\hline Access to the Financial Aid office during evenings & $0 \%$ & $100 \%$ & $0 \%$ \\
\hline $\begin{array}{l}\text { Access to information via computer with the Financial Aid } \\
\text { office }\end{array}$ & $14 \%$ & $86 \%$ & $0 \%$ \\
\hline
\end{tabular}

The summary of the population's responses for the financial aid is depicted in Table 52.

Table 52

Financial Aid Services: Total Population

Publications that outline financial aid programs and services for adult students

Assistance for adult students in completing financial aid forms

Loan programs designed specifically for adult students Scholarship programs designed specifically for adult students

Access to the Financial Aid office during evenings

Access to information via computer with the Financial Aid office

\begin{tabular}{|c|c|c|}
\hline 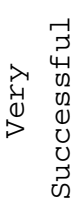 & $\begin{array}{l}-1 \\
3 \\
4 \\
0 \\
0 \\
02 \\
0 \\
0 \\
0 \\
0 \\
0 \\
0\end{array}$ & $\begin{array}{cc} & 7 \\
& 5 \\
& 4 \\
& 4 \\
0 & 0 \\
0 & 0 \\
2 & 0 \\
& 0 \\
& 0 \\
& 0 \\
& 5 \\
& 0\end{array}$ \\
\hline $27 \%$ & $73 \%$ & $0 \%$ \\
\hline $21 \%$ & $74 \%$ & $5 \%$ \\
\hline $40 \%$ & $60 \%$ & $0 \%$ \\
\hline $43 \%$ & $57 \%$ & $0 \%$ \\
\hline $0 \%$ & $100 \%$ & $0 \%$ \\
\hline $17 \%$ & $75 \%$ & $8 \%$ \\
\hline
\end{tabular}

Public institutions rated all six financial aid services as "successful" in attracting adult students. The service of loan programs designed for adult students was given an equal percentage of 50\% between "successful" and 
"very successful." Private institutions also rated all six services as "successful" in attracting adult students. The service of scholarship programs designed for adult students received an equal percentage between "successful" and "very successful."

The population rated all six services as "successful" in attracting adult students. The greatest percentage (100\%) was assigned to the service of access to the financial aid office during evenings.

Food Services: Tables 53-55

The population was asked to rate the success in attracting adult students to the four food services identified in the survey. The responses for each item for the public institutions are summarized in Table 53.

Table 53

Food Services: Public Institutions 


\begin{tabular}{|c|c|c|c|}
\hline & 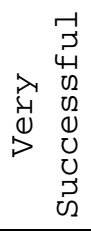 & 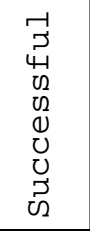 & 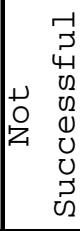 \\
\hline Vending area open during evenings and weekends & $13 \%$ & $87 \%$ & $0 \%$ \\
\hline Snack bar open during evenings and weekends & $13 \%$ & $87 \%$ & $0 \%$ \\
\hline Full service cafeteria open during evenings & $17 \%$ & $50 \%$ & $33 \%$ \\
\hline Charge cards available for convenience & $13 \%$ & $74 \%$ & $13 \%$ \\
\hline
\end{tabular}

Table 54 reports the responses for the items in the category of food services for the private institutions.

Table 54

Food Services: Private Institutions

\begin{tabular}{|c|c|c|c|}
\hline & 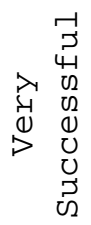 & $\begin{array}{l}-1 \\
3 \\
4-1 \\
02 \\
02 \\
0 \\
0 \\
0 \\
5 \\
0 \\
02\end{array}$ & 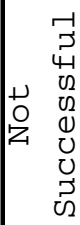 \\
\hline Vending area open during evenings and weekends & $31 \%$ & $46 \%$ & $23 \%$ \\
\hline Snack bar open during evenings and weekends & $18 \%$ & $55 \%$ & $27 \%$ \\
\hline Full service cafeteria open during evenings & $20 \%$ & $60 \%$ & $20 \%$ \\
\hline Charge cards available for convenience & $20 \%$ & $80 \%$ & $0 \%$ \\
\hline
\end{tabular}

The summary of the population's responses for the category of food services is detailed in Table 55.

Table 55 
Food Services - Total Population

\begin{tabular}{|c|c|c|c|}
\hline & 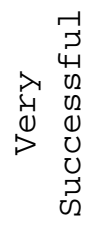 & $\begin{array}{l}71 \\
3 \\
4 \\
02 \\
02 \\
0 \\
0 \\
0 \\
2 \\
2 \\
0\end{array}$ & 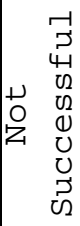 \\
\hline Vending area open during evenings and weekends & $24 \%$ & $62 \%$ & $14 \%$ \\
\hline Snack bar open during evenings and weekends & $16 \%$ & $68 \%$ & $16 \%$ \\
\hline Full service cafeteria open during evenings & $20 \%$ & $50 \%$ & $30 \%$ \\
\hline Charge cards available for convenience & $17 \%$ & $75 \%$ & $8 \%$ \\
\hline
\end{tabular}

Public institutions rated all four food services as "successful" in attracting adult students. However, the survey question regarding the success of the full-service cafeteria in attracting adult students had a relatively high percentage of 33\% for "not successful".

Private institutions also rated all four food services as "successful" in attracting adult students with a much more even distribution of the percentages among the three ratings.

The population rated all four food services as "successful" in attracting adult students with the service of full-service cafeteria having the highest percentage of "not successful" at $30 \%$ Orientation Services: Tables 56-58

The population was asked to rate the success in attracting adult students to the three orientation services identified in the survey. The responses for each item for the public institutions are presented in Table 56. Table 56 


\begin{tabular}{|c|c|c|c|}
\hline & 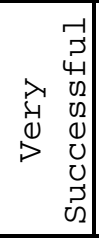 & $\begin{array}{l}-1 \\
5 \\
4 \\
01 \\
02 \\
02 \\
0 \\
0 \\
0 \\
0 \\
02 \\
0 \\
\end{array}$ & \begin{tabular}{|ll} 
& \multicolumn{1}{r}{} \\
& 5 \\
& \\
& 4 \\
1 & 0 \\
0 & 0 \\
0 & 0 \\
2 & 0 \\
& 0 \\
& 0 \\
& 5 \\
& \\
0
\end{tabular} \\
\hline $\begin{array}{l}\text { Continuous orientation program during the first semester } \\
\text { directed toward adult students and their needs }\end{array}$ & $0 \%$ & $100 \%$ & $0 \%$ \\
\hline General orientation program designed for adult students & $0 \%$ & $100 \%$ & $0 \%$ \\
\hline $\begin{array}{l}\text { Peer advising program - returning adult students advise } \\
\text { new adult students }\end{array}$ & $0 \%$ & $100 \%$ & $0 \%$ \\
\hline
\end{tabular}

Table 57 portrays the responses for the items in the category of orientation services for the private institutions.

Table 57

Orientation Services: Private Institutions

\begin{tabular}{|c|c|c|c|}
\hline & 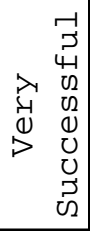 & $\begin{array}{l}-1 \\
2 \\
41 \\
02 \\
02 \\
0 \\
0 \\
0 \\
0 \\
5 \\
02\end{array}$ & 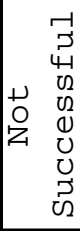 \\
\hline $\begin{array}{l}\text { Continuous orientation program during the first semester } \\
\text { directed toward adult students and their needs }\end{array}$ & $40 \%$ & $60 \%$ & $0 \%$ \\
\hline General orientation program designed for adult students & $40 \%$ & $60 \%$ & $0 \%$ \\
\hline $\begin{array}{l}\text { Peer advising program - returning adult students advise } \\
\text { new adult students }\end{array}$ & $0 \%$ & $100 \%$ & $0 \%$ \\
\hline
\end{tabular}

The summary of the population's responses for the category of orientation services is displayed in Table 58.

Table 58

Orientation Services: Total Population 


\begin{tabular}{|c|c|c|c|}
\hline & 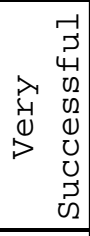 & $\begin{array}{l}-1 \\
5 \\
41 \\
02 \\
02 \\
0 \\
0 \\
0 \\
J \\
3 \\
0\end{array}$ & 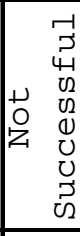 \\
\hline $\begin{array}{l}\text { Continuous orientation program during the first semester } \\
\text { directed toward adult students and their needs }\end{array}$ & $33 \%$ & $67 \%$ & $0 \%$ \\
\hline General orientation program designed for adult students & $33 \%$ & $67 \%$ & $0 \%$ \\
\hline $\begin{array}{l}\text { Peer advising program - returning adult students advise } \\
\text { new adult students }\end{array}$ & $0 \%$ & $100 \%$ & $0 \%$ \\
\hline
\end{tabular}

Public institutions gave percentages of $100 \%$ to the three orientation services for being "successful" in attracting adult students. The private institutions also rated all three services as "successful" in attracting adult students although only the service of peer advising received a percentage of $100 \%$. The population reflected the ratings for the private institutions with the three orientation services judged as "successful" in attracting adult students. The peer advising program had the highest percentage at $100 \%$. No orientation services were rated as "not successful" in attracting adult students. College Personnel Services: Tables 59-61

The population was asked to rate the success in attracting adult students to the three college personnel services identified in the survey. The responses for each item for the public institutions are presented in Table 59. Table 59

College Personnel: Public Institutions 


\begin{tabular}{|c|c|c|c|}
\hline & 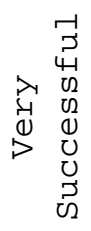 & $\begin{array}{l}-1 \\
5 \\
4 \\
02 \\
02 \\
0 \\
0 \\
0 \\
U \\
כ \\
2 \\
0\end{array}$ & 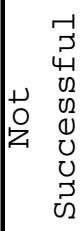 \\
\hline $\begin{array}{l}\text { Administrators and staff who have experience working with } \\
\text { adult students }\end{array}$ & $25 \%$ & $75 \%$ & $0 \%$ \\
\hline Faculty who have experience working with adult students & $20 \%$ & $80 \%$ & $0 \%$ \\
\hline $\begin{array}{l}\text { Administrators and staff trained in understanding adult } \\
\text { development and adult learning characteristics }\end{array}$ & $0 \%$ & $100 \%$ & $0 \%$ \\
\hline
\end{tabular}

Table 60 displays the responses for the item in the category of college personnel for the private institutions. Table 60

\section{College Personnel: Private Institutions}

\begin{tabular}{|c|c|c|c|}
\hline & 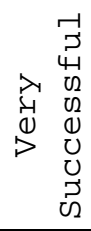 & $\begin{array}{l}-1 \\
3 \\
4-1 \\
02 \\
02 \\
0 \\
0 \\
0 \\
5 \\
02 \\
0\end{array}$ & 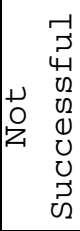 \\
\hline $\begin{array}{l}\text { Administrators and staff who have experience working with } \\
\text { adult students }\end{array}$ & $33 \%$ & $54 \%$ & $13 \%$ \\
\hline Faculty who have experience working with adult students & $43 \%$ & $57 \%$ & $0 \%$ \\
\hline $\begin{array}{l}\text { Administrators and staff trained in understanding adult } \\
\text { development and adult learning characteristics }\end{array}$ & $23 \%$ & $67 \%$ & $0 \%$ \\
\hline
\end{tabular}

The summary of the population's responses for the category of college personnel services is depicted in Table 61.

Table 61

College Personnel: Total Population 


\begin{tabular}{|c|c|c|c|}
\hline & 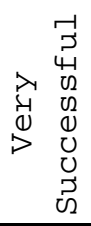 & $\begin{array}{l}-1 \\
5 \\
4-1 \\
02 \\
02 \\
0 \\
0 \\
0 \\
J \\
2 \\
2\end{array}$ & 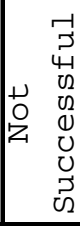 \\
\hline $\begin{array}{l}\text { Administrators and staff who have experience working with } \\
\text { adult students }\end{array}$ & $31 \%$ & $58 \%$ & $11 \%$ \\
\hline Faculty who have experience working with adult students & $37 \%$ & $63 \%$ & $0 \%$ \\
\hline $\begin{array}{l}\text { Administrators and staff trained in understanding adult } \\
\text { development and adult learning characteristics }\end{array}$ & $27 \%$ & $76 \%$ & $0 \%$ \\
\hline
\end{tabular}

Public institutions rated all three services as

"successful" in attracting adult students. None of the services received ratings of "not successful" from these institutions. Private colleges and the population also rated the three college personnel services as "successful" in attracting adult students with the highest percentage given to the service of administrators and staff who are trained in understanding adult development and adult learning characteristics.

Registration Services: Tables 62-65

The population was asked to rate the success in attracting adult students to the seven registration services identified in the survey. The responses for each item for the public institutions are presented in Table 62 .

Table 62

Registration Services: Public Institutions 


\begin{tabular}{|c|c|c|c|}
\hline & 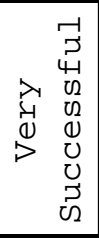 & $\begin{array}{l}-1 \\
3 \\
3 \\
4 \\
0 \\
0 \\
0 \\
0 \\
0 \\
0 \\
J \\
0 \\
0 \\
\end{array}$ & 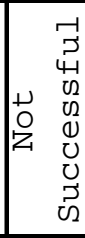 \\
\hline Registration assistance provided for adult students & $20 \%$ & $80 \%$ & $0 \%$ \\
\hline Pre-registration available to accommodate students & $29 \%$ & $71 \%$ & $0 \%$ \\
\hline Registration by mail & $0 \%$ & $100 \%$ & $0 \%$ \\
\hline Registration by phone & $20 \%$ & $80 \%$ & $0 \%$ \\
\hline Registration by e-mail & $0 \%$ & $100 \%$ & $0 \%$ \\
\hline Registrar's office open during evenings & $0 \%$ & $100 \%$ & $0 \%$ \\
\hline $\begin{array}{l}\text { Access to information via the computer with the } \\
\text { Registrar's office }\end{array}$ & $38 \%$ & $62 \%$ & $0 \%$ \\
\hline
\end{tabular}

Table 63 reports the responses for the items in the category of registration services for the private institutions.

Table 63

Registration Services: Private Institutions

\begin{tabular}{|c|c|c|c|}
\hline & 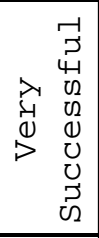 & $\begin{array}{l}-1 \\
5 \\
4 \\
01 \\
02 \\
0 \\
0 \\
0 \\
0 \\
J \\
0 \\
0 \\
\end{array}$ & 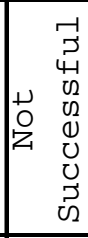 \\
\hline Registration assistance provided for adult students & $38 \%$ & $54 \%$ & $8 \%$ \\
\hline Pre-registration available to accommodate students & $43 \%$ & $50 \%$ & 7\% \\
\hline Registration by mail & $44 \%$ & $56 \%$ & $0 \%$ \\
\hline Registration by phone & $50 \%$ & $50 \%$ & $0 \%$ \\
\hline Registration by e-mail & $0 \%$ & $100 \%$ & $0 \%$ \\
\hline Registrar's office open during evenings & $0 \%$ & $100 \%$ & $0 \%$ \\
\hline $\begin{array}{l}\text { Access to information via the computer with the } \\
\text { Registrar's office }\end{array}$ & $33 \%$ & $64 \%$ & $0 \%$ \\
\hline
\end{tabular}

The summary of the population's responses for the category of registration services is described in Table 64 . Table 64

$\underline{\text { Registration Services: Total Population }}$ 


\begin{tabular}{|c|c|c|c|}
\hline & 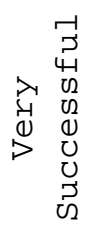 & $\begin{array}{l}-1 \\
3 \\
41 \\
02 \\
02 \\
0 \\
0 \\
0 \\
J \\
2 \\
0\end{array}$ & 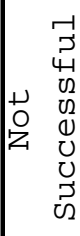 \\
\hline Registration assistance provided for adult students & $33 \%$ & $61 \%$ & $5 \%$ \\
\hline Pre-registration available to accommodate students & $38 \%$ & $57 \%$ & $5 \%$ \\
\hline Registration by mail & $31 \%$ & $69 \%$ & $0 \%$ \\
\hline Registration by phone & $33 \%$ & $67 \%$ & $0 \%$ \\
\hline Registration by e-mail & $0 \%$ & $100 \%$ & $0 \%$ \\
\hline Registrar's office open during evenings & $0 \%$ & $100 \%$ & $0 \%$ \\
\hline $\begin{array}{l}\text { Access to information via the computer with the } \\
\text { Registrar's office }\end{array}$ & $36 \%$ & $64 \%$ & $0 \%$ \\
\hline
\end{tabular}

Public institutions rated all seven services as "successful" in attracting adult students. No service was judged as being "not successful". The private institutions also rated all seven services as "successful" in attracting adult students. The private institutions also gave the services higher ratings for "very successful" than did the public institutions.

The population rated all registration services as "successful" in attracting adult students. In particular, the services of registrar's office open during evenings and registration by e-mail were given percentage of $100 \%$ in the "successful" category. Student Activities Services: Tables 65-67

The population was asked to rate the success in attracting adult students to the five student activities 
services identified in the survey. The responses for each item for the public institutions are presented in Table 65 . Table 65

Student Activities: Public Institutions

\begin{tabular}{|c|c|c|c|}
\hline & 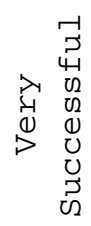 & $\begin{array}{l}-1 \\
3 \\
4 \\
02 \\
02 \\
0 \\
0 \\
0 \\
0 \\
5 \\
02\end{array}$ & 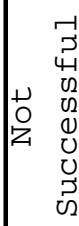 \\
\hline Adult student organization(s) & $0 \%$ & $75 \%$ & $25 \%$ \\
\hline Recreational facilities available during evenings & $17 \%$ & $83 \%$ & $0 \%$ \\
\hline Recreational facilities available to student families & $0 \%$ & $80 \%$ & $20 \%$ \\
\hline Student governance opportunities for adult students & $0 \%$ & $50 \%$ & $50 \%$ \\
\hline Cultural activities and programs & $0 \%$ & $100 \%$ & $0 \%$ \\
\hline
\end{tabular}

Table 66 shows the responses for the items in the category of student activities for the private institutions. Table 66

Student Activities: Private Institutions

\begin{tabular}{|c|c|c|c|}
\hline & 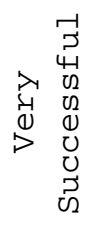 & $\begin{array}{l}-1 \\
3 \\
4 \\
02 \\
02 \\
01 \\
0 \\
0 \\
5 \\
02\end{array}$ & 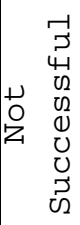 \\
\hline Adult student organization(s) & $11 \%$ & $56 \%$ & $33 \%$ \\
\hline Recreational facilities available during evenings & $25 \%$ & $58 \%$ & $17 \%$ \\
\hline Recreational facilities available to student families & $27 \%$ & $64 \%$ & $9 \%$ \\
\hline Student governance opportunities for adult students & $22 \%$ & $33 \%$ & $45 \%$ \\
\hline Cultural activities and programs & $14 \%$ & $79 \%$ & $7 \%$ \\
\hline
\end{tabular}

The summary of the population's responses for the category of student activities is displayed in Table 67. Table 67

Student Activities: Total Population 


\begin{tabular}{|c|c|c|c|}
\hline & 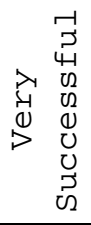 & $\begin{array}{l}-1 \\
2 \\
4 \\
02 \\
0 \\
0 \\
0 \\
0 \\
5 \\
0 \\
0\end{array}$ & 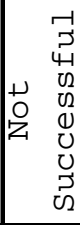 \\
\hline Adult student organization (s) & $8 \%$ & $62 \%$ & $30 \%$ \\
\hline Recreational facilities available during evenings & $22 \%$ & $67 \%$ & $11 \%$ \\
\hline Recreational facilities available to student families & $19 \%$ & $69 \%$ & $12 \%$ \\
\hline Student governance opportunities for adult students & $13 \%$ & $40 \%$ & $47 \%$ \\
\hline Cultural activities and programs & $14 \%$ & $86 \%$ & $0 \div$ \\
\hline
\end{tabular}

The public institutions rated four of the five services as "successful" in attracting adult students. The fifth service, student governance opportunities for adult students, was given equal percentages of $50 \%$ between the categories of "successful" and "not successful". The private institutions also gave ratings of "successful" in attracting adult students to four of the five services. The service of student governance opportunities was given a rating of "not successful" in attracting adult students.

The population gave four of the student activities services ratings of "successful" in attracting adult students. Student governance opportunities had a percentage of $47 \%$ for the rating of "not successful" in attracting adult students. This was the only service in the entire survey to receive this rating.

Educational Support Services: Tables 68-70

The population was asked to rate the success in attracting adult students to the eleven educational support services identified in the survey. The responses for each item for the public institutions are presented in Table 68 . 
Table 68

Educational Support Services: Public Institutions

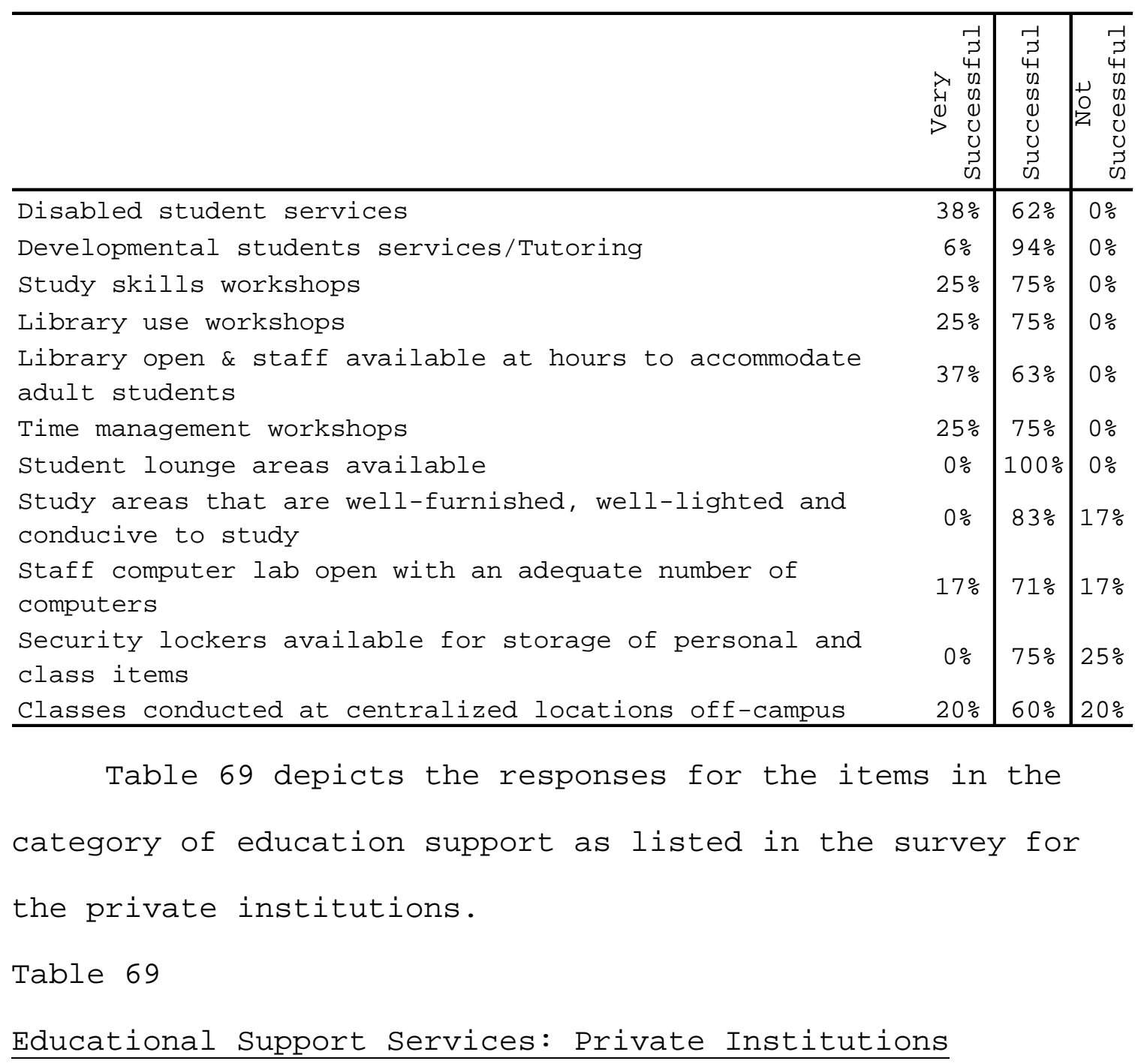




\begin{tabular}{|c|c|c|c|}
\hline & 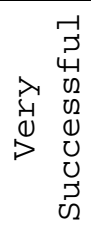 & 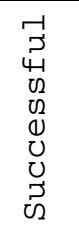 & 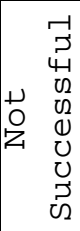 \\
\hline Disabled student services & $7 \%$ & $86 \%$ & $7 \%$ \\
\hline Developmental students services/Tutoring & $36 \%$ & $57 \%$ & $7 \%$ \\
\hline Study skills workshops & $22 \%$ & $64 \%$ & $14 \%$ \\
\hline Library use workshops & $36 \%$ & $50 \%$ & $14 \%$ \\
\hline $\begin{array}{l}\text { Library open \& staff available at hours to accommodate } \\
\text { adult students }\end{array}$ & $38 \%$ & $54 \%$ & $8 \%$ \\
\hline Time management workshops & $27 \%$ & $55 \%$ & $18 \%$ \\
\hline Student lounge areas available & $0 \%$ & $79 \%$ & $21 \%$ \\
\hline $\begin{array}{l}\text { Study areas that are well-furnished, well-lighted and } \\
\text { conducive to study }\end{array}$ & $0 \%$ & $92 \%$ & $8 \%$ \\
\hline $\begin{array}{l}\text { Staff computer lab open with an adequate number of } \\
\text { computers }\end{array}$ & $27 \%$ & $67 \%$ & $6 \%$ \\
\hline $\begin{array}{l}\text { Security lockers available for storage of personal and } \\
\text { class items }\end{array}$ & $14 \%$ & $57 \%$ & $29 \%$ \\
\hline Classes conducted at centralized locations off-campus & $43 \%$ & $57 \%$ & $0 \%$ \\
\hline
\end{tabular}

The summary of the population's responses for the category of educational support is described in Table 70. 
Table 70

Educational Support Services: Total Population

\begin{tabular}{|c|c|c|c|}
\hline & 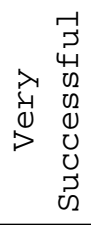 & $\begin{array}{l}71 \\
2 \\
4 \\
02 \\
02 \\
0 \\
0 \\
0 \\
0 \\
5 \\
02 \\
0\end{array}$ & 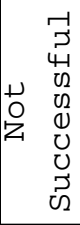 \\
\hline Disabled student services & $18 \%$ & $77 \%$ & $5 \%$ \\
\hline Developmental students services/Tutoring & $30 \%$ & $65 \%$ & $5 \%$ \\
\hline Study skills workshops & $23 \%$ & $68 \%$ & $9 \%$ \\
\hline Library use workshops & $32 \%$ & $59 \%$ & $9 \%$ \\
\hline $\begin{array}{l}\text { Library open \& staff available at hours to accommodate } \\
\text { adult students }\end{array}$ & $38 \%$ & $57 \%$ & $5 \%$ \\
\hline Time management workshops & $26 \%$ & $63 \%$ & $14 \%$ \\
\hline Student lounge areas available & $0 \%$ & $90 \%$ & $10 \%$ \\
\hline $\begin{array}{l}\text { Study areas that are well-furnished, well-lighted and } \\
\text { conducive to study }\end{array}$ & $0 \%$ & $89 \%$ & $11 \%$ \\
\hline $\begin{array}{l}\text { Staff computer lab open with an adequate number of } \\
\text { computers }\end{array}$ & $23 \%$ & $68 \%$ & $9 \%$ \\
\hline $\begin{array}{l}\text { Security lockers available for storage of personal and } \\
\text { class items }\end{array}$ & $9 \%$ & $64 \%$ & $27 \%$ \\
\hline Classes conducted at centralized locations off-campus & $33 \%$ & $58 \%$ & $9 \%$ \\
\hline
\end{tabular}

Both the public and private institutions gave the

eleven educational support services "successful" ratings for attracting adult students. However, the item of security lockers was given a relatively high percentage of $25 \%$ for being "not successful" in attracting adult students. Residential Life Services: Tables 71-73

The population was asked to rate the success in attracting adult students to the two residential life services identified in the survey. The responses for each item for the public institutions are presented in Table 71 . Table 71 
Residential Life Services: Public Institutions

\begin{tabular}{|c|c|c|c|}
\hline & 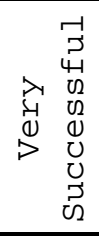 & $\begin{array}{l}-1 \\
5 \\
4 \\
0 \\
02 \\
0 \\
0 \\
0 \\
0 \\
0 \\
5 \\
0 \\
0\end{array}$ & 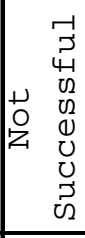 \\
\hline $\begin{array}{l}\text { Provision of overnight and/or weekend accommodations at } \\
\text { reasonable cost }\end{array}$ & $0 \%$ & $50 \%$ & $50 \%$ \\
\hline Residential staff trained to work with adult students & $0 \%$ & $100 \%$ & $0 \div$ \\
\hline
\end{tabular}

Table 72 details the responses for the items in the category of residential life for the private institutions. Table 72

Residential Life Services: Private Institutions

\begin{tabular}{|c|c|c|c|}
\hline & 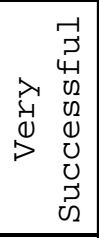 & $\begin{array}{l}-1 \\
3 \\
3 \\
4 \\
02 \\
02 \\
0 \\
0 \\
0 \\
0 \\
0 \\
0 \\
\end{array}$ & 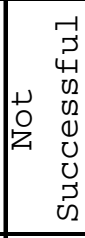 \\
\hline $\begin{array}{l}\text { Provision of overnight and/or weekend accommodations at } \\
\text { reasonable cost }\end{array}$ & $0 \%$ & $66 \%$ & $44 \%$ \\
\hline Residential staff trained to work with adult students & $0 \%$ & $100 \div$ & $0 \%$ \\
\hline
\end{tabular}

The summary of the population's responses for the category of residential life services is portrayed in Table 73. 
Table 73

Residential Life Services: Total Population

\begin{tabular}{|c|c|c|c|}
\hline & 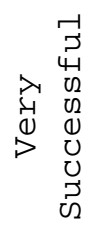 & $\begin{array}{l}71 \\
3 \\
4 \\
02 \\
02 \\
0 \\
0 \\
0 \\
2 \\
2 \\
02\end{array}$ & 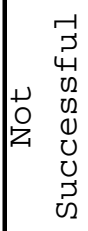 \\
\hline $\begin{array}{l}\text { Provision of overnight and/or weekend accommodations at } \\
\text { reasonable cost }\end{array}$ & $0 \%$ & $63 \div$ & $36 \%$ \\
\hline Residential staff trained to work with adult students & $0 \%$ & $100 \%$ & $0 \%$ \\
\hline
\end{tabular}

The public institutions gave the percentage of $100 \%$ to the service of residential staff who are trained to work with adult students considering it to be "successful" in attracting adult students. The item of overnight/weekend accommodations was given equal percentages of $50 \%$ between the ratings "successful" and "not successful" in attracting adult students.

The private institutions also gave the service of residential staff who are trained a percentage of $100 \%$ for "successful" in attracting adult students and slightly lower percentage of $64 \%$ to "successful" for the service of overnight/weekend accommodations. However, this service received a relatively high percentage of $44 \%$ for being "not successful" in attracting adult students.

The population rated the two residential life services as "successful" in attracting adult students. The service of overnight/weekend accommodations was given a ranking of 36\% for the rating of "unsuccessful." 
Parking and Transportation Services: Tables 74-76

The population was asked to rate the success in attracting adult students to the three parking and transportation services identified in the survey. The responses for each item for the public institutions are shown in Table 74 .

Table 74

Parking and Transportation Services: Public Institutions

\begin{tabular}{|c|c|c|c|}
\hline & 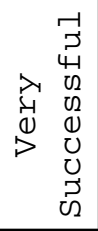 & $\begin{array}{l}-1 \\
3 \\
4 \\
0 \\
0 \\
0 \\
0 \\
0 \\
0 \\
5 \\
0 \\
0\end{array}$ & 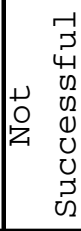 \\
\hline Bus service to campus buildings from parking areas & $20 \%$ & $80 \%$ & $0 \%$ \\
\hline Adequate and well-lighted parking & $29 \%$ & $71 \%$ & $0 \%$ \\
\hline Security personnel on duty at all times & $50 \%$ & $50 \%$ & $0 \%$ \\
\hline
\end{tabular}

Table 75 summarizes the responses for the items in the category of parking and transportation for the private institutions. 
Table 75

Parking and Transportation: Private Institutions

\begin{tabular}{|c|c|c|c|}
\hline & 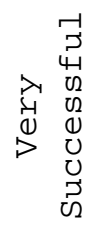 & $\begin{array}{l}-1 \\
3 \\
4 \\
02 \\
02 \\
0 \\
0 \\
0 \\
0 \\
5 \\
02\end{array}$ & 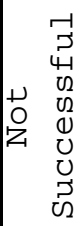 \\
\hline Bus service to campus buildings from parking areas & $50 \%$ & $50 \%$ & $0 \%$ \\
\hline Adequate and well-lighted parking & $40 \%$ & $53 \%$ & $7 \%$ \\
\hline Security personnel on duty at all times & $38 \%$ & $62 \%$ & $0 \%$ \\
\hline
\end{tabular}

The summary of the population's responses for the category of parking and transportation is reported in Table 76.

Table 76

$\underline{\text { Parking and Transportation: Total Population }}$

\begin{tabular}{|c|c|c|c|}
\hline & 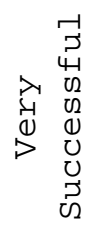 & $\begin{array}{l}71 \\
3 \\
4 \\
02 \\
02 \\
0 \\
0 \\
0 \\
2 \\
2 \\
02\end{array}$ & 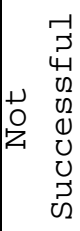 \\
\hline Bus service to campus buildings from parking areas & $33 \%$ & $67 \%$ & $0 \%$ \\
\hline Adequate and well-lighted parking & $36 \%$ & $59 \%$ & $5 \%$ \\
\hline Security personnel on duty at all times & $43 \%$ & $57 \%$ & $0 \%$ \\
\hline
\end{tabular}

Public institutions yeilded ratings of "successful" to the three parking and transportation items for attracting adult students. The service of security personnel was given an equal percentage of $50 \%$ between the ratings of "successful" and "very successful". No services were given the rating of "not successful" in attracting adult students. Private institutions rated the three services as "successful" in attracting adult students. Equal 


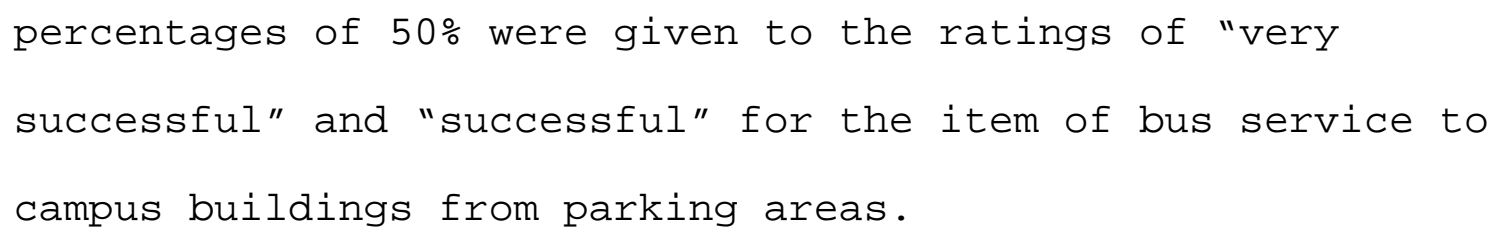

The population gave the three parking and transportation services ratings of "successful" in attracting adult students with relatively high percentages (33\%-43\%) for the rating of "very successful." Miscellaneous Services: Tables 77-79

The population was asked to rate the success in attracting adult students to the three miscellaneous services identified in the survey. The responses for each item for the public institutions are presented in Table 77 . Table 77

Miscellaneous Services: Public Institutions

\begin{tabular}{|c|c|c|c|}
\hline & 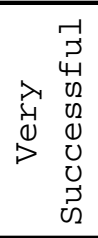 & $\begin{array}{l}7 \\
3 \\
4 \\
0 \\
0 \\
0 \\
0 \\
0 \\
0 \\
0 \\
5 \\
0\end{array}$ & 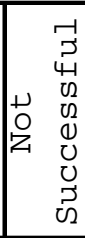 \\
\hline Student health services & $13 \%$ & $87 \%$ & $0 \%$ \\
\hline Child care services & $33 \%$ & $33 \%$ & $33 \%$ \\
\hline Child care referral services & $25 \%$ & $75 \%$ & $0 \%$ \\
\hline
\end{tabular}

Table 78 depicts the responses for the items in the category of miscellaneous services as listed in the survey for the private institutions.

Table 78 Miscellaneous Services: Private Institutions 


\begin{tabular}{|c|c|c|c|}
\hline & 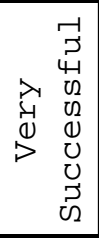 & $\begin{array}{l}71 \\
5 \\
4 \\
0 \\
02 \\
02 \\
0 \\
0 \\
0 \\
J \\
0 \\
2 \\
\end{array}$ & 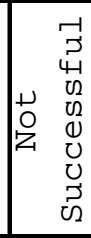 \\
\hline Student health services & $17 \%$ & $66 \%$ & $17 \%$ \\
\hline Child care services & $0 \%$ & $100 \%$ & $0 \%$ \\
\hline Child care referral services & $0 \%$ & $100 \%$ & $0 \%$ \\
\hline
\end{tabular}

The summary of the population's responses for the category of miscellaneous services is detailed in Table 79. Table 79

Miscellaneous Services: Total Population

\begin{tabular}{|c|c|c|c|}
\hline & $\begin{array}{rl} & -7 \\
& \\
& 4 \\
\lambda & 0 \\
4 & 0 \\
0 & 0 \\
0 & 0 \\
> & U \\
0 \\
D \\
0\end{array}$ & $\begin{array}{l}-1 \\
3 \\
4 \\
02 \\
00 \\
0 \\
0 \\
0 \\
0 \\
2 \\
0\end{array}$ & \begin{tabular}{rrr} 
& \multicolumn{1}{r}{} \\
& 5 \\
& 4 \\
& 4 \\
& 0 \\
0 & 0 \\
0 & 0 \\
2 & 0 \\
& 0 \\
& 0 \\
& $D$ \\
& 2
\end{tabular} \\
\hline Student health services & $14 \%$ & $78 \%$ & $8 \%$ \\
\hline Child care services & $17 \%$ & $66 \%$ & $17 \%$ \\
\hline Child care referral services & $14 \%$ & $86 \%$ & $0 \%$ \\
\hline
\end{tabular}

The public institutions gave the items of student health services and child care referral services ratings of "successful" in attracting adult students. The item child care services received equal percentages of 33\% for the ratings of "very successful", "successful", and "not successful." The private institutions rated all three services as "successful" in attracting adult students. The population rated all three miscellaneous services as "successful" in attracting adult students with nominal rankings assigned to the rating of "very successful." 


\section{Additional Student Services}

The data for research question \#3 identified additional student services needed to accommodate adult students. The respondents were given an open-ended question for this item. Of the 26 administrators who responded, three provided comments. Presented below are the responses the respondents furnished. "Non-traditional aged transfer student orientation is needed for full-time undergraduates $24+$ with peer advisors." "All adult students 25 years or older are automatically given a 50\% discount on tuition costs." "Orientation for families, spouses, children, etc. is needed." "Alumni events would be helpful." "Student handbooks would be advantageous."

\section{Summary}

The results of this study provide a description of the student services that are currently available to adult students attending undergraduate four-year institutions, the success of the available services in attracting adult students, and the additional services that are needed to accommodate adult students.

Fifty of the 65 services from the survey list were reported as being available at the majority of public institutions. The categories available at most of the institutions included counseling, Food Service, College 
Personnel, Student Activities, Educational Support, and Parking \& Transportation.

At the majority of the private institutions, 40 of the 65 services were identified from the survey list as being available at their institutions. Most of the private institutions offered all of the student services listed under the categories of Counseling, College Personnel, and Student Activities.

When the responses from the public and private institutions are combined, 47 of the 65 student services were identified as being available at most of the institutions. All the student services under the categories of Counseling, Student Activities, and Educational Support services were provided at most of the institutions.

The services identified as being currently available were, generally, considered to be "successful" in attracting adult students. The population identified three services in the category of Admissions that they rated as "very successful" in attracting adult students. Those services were 1) academic credit for work experience or training; 2) the option to pursue degree on a part-time basis program; and 3 ) access to the Admissions office during evenings. The population also identified one service as "not successful" in attracting adult students which was student governance opportunities for adult students. 
The population did not provide sufficient data for determining if additional student services were needed for adult students. Only three respondents provided data for the third research question. While these data are limited, the comments that were supplied provide suggestions to administrators when planning for programs and services more suitable for the adult student population. 


\section{CHAPTER FIVE}

CONCLUSIONS AND RECOMMENDATIONS

This chapter is organized into four sections. The first is a brief review of the problem, literature and research methodology. A summary of the findings is presented in the second. The third presents the conclusions of those findings and recommendations based on the data in Chapter Four. Conclusions are provided for each of the thirteen student services categories listed in the survey. Recommendations for further studies are presented in the final section.

Review of Problem, Literature and Methodology

Adult learners (students over 25 years of age) constitute an increasing percentage of college students in the United States. This increase in enrollment of older undergraduate students has occurred in response to two national trends: greater numbers of women entering the workforce, and a growing educational need of American workers for job retraining, advancement, or change (ElKhawas, 1996). The special needs of this population continue to change, which places significant stress on many 
of the current student services being offered at higher education institutions.

Institutional response to new student populations at the undergraduate level has often been inadequate and inappropriate. Many colleges and universities continue to operate as though a college education means 120 credit hours of course work completed by students between the ages of eighteen and twenty-four. Rather than anticipating the unique needs of new types of students and then modifying existing programs and creating new ones to respond more adequately to those needs, colleges and universities frequently have attempted to fit nontraditional students into traditional programs and services.

The purpose of this study was to discover the student services available to adult students attending Virginia's 15 public and 27 private undergraduate four-year colleges, in order to determine which of these services were successful or unsuccessful in attracting adult students and to ascertain if there were additional student services needed to accommodate the students. The quality of the services was not addressed.

This was a descriptive study using quantitative methods. The population for this study consisted of the chief student affairs administrators at the four-year 
undergraduate institutions in the Commonwealth of Virginia. A self-reporting survey instrument was developed by the researcher and was generated from information identified through a review of research and related literature. Data collection was accomplished by mailing the instrument to the population in January 1998. After planned follow-up procedures by mail, e-mail and telephone were exhausted, a total of 26 usable responses had been obtained, representing an effective response rate of 62 percent.

\section{Summary of Results}

The responses of the population are summarized in Table 80. The mean percentages of "yes" responses regarding the availability of the student services at the public and private institutions identified in the survey are presented in Table 80. The table also illustrates the degree of success in attracting adult students to the services. The services are listed in the order in which they appeared in the survey. The responses for research question \#3 are shown after the tables. 
Table 80

Population Summary: Availability and Degree of Success for $\underline{\text { Student Services }}$

\begin{tabular}{|c|c|c|c|}
\hline STUDENT SERVICE & 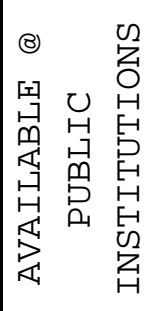 & 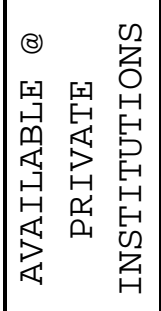 & 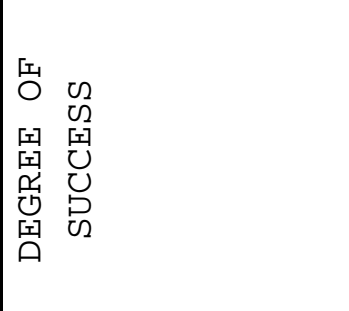 \\
\hline \multicolumn{4}{|l|}{ Admissions } \\
\hline Recruitment materials & $38 \%$ & $73 \%$ & Successful \\
\hline Direct Recruitment of Adults & $50 \%$ & $71 \%$ & Successful \\
\hline Personnel recruitment visits & $63 \%$ & $47 \%$ & Successful \\
\hline Special admissions criteria & $43 \%$ & $47 \%$ & Successful \\
\hline Advanced credit & $50 \%$ & $67 \%$ & Very Successful \\
\hline Part-time degree & $71 \%$ & $77 \%$ & Very Successful \\
\hline Admissions office open & $38 \%$ & $57 \%$ & Very Successful \\
\hline Admissions access via computer & $88 \%$ & $87 \%$ & Successful \\
\hline \multicolumn{4}{|l|}{ Business } \\
\hline Tuition Installment Plan & $88 \%$ & $93 \%$ & Successful \\
\hline Access to Business Office & $25 \%$ & $33 \%$ & Successful \\
\hline Access via computer & $50 \%$ & $33 \%$ & Successful \\
\hline \multicolumn{4}{|l|}{ Counseling } \\
\hline Academic Advising & $88 \%$ & $93 \%$ & Successful \\
\hline Career Counseling & $50 \%$ & $67 \%$ & Successful \\
\hline Referral to specialists & $63 \%$ & $64 \%$ & Successful \\
\hline Counseling training & $63 \%$ & $57 \%$ & Successful \\
\hline Job placement & $63 \%$ & $79 \%$ & Successful \\
\hline Access to Career Services & $50 \%$ & $73 \%$ & Successful \\
\hline Access via computer & $75 \%$ & $60 \%$ & Successful \\
\hline \multicolumn{4}{|l|}{ Financial Aid } \\
\hline Publications & $25 \%$ & $60 \%$ & Successful \\
\hline Assistance with forms & $88 \%$ & $80 \%$ & Successful \\
\hline Loan programs & $25 \%$ & $20 \%$ & Successful \\
\hline Scholarship programs & $13 \%$ & $43 \%$ & Successful \\
\hline Access to office & $13 \%$ & $13 \%$ & Successful \\
\hline Access via computer & $63 \%$ & $47 \%$ & Successful \\
\hline
\end{tabular}


Table 80 Continued...

Population Summary: Availability and Degree of Success for $\underline{\text { Student Services }}$

\begin{tabular}{|c|c|c|c|}
\hline STUDENT SERVICE & 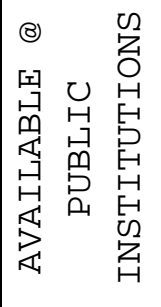 & 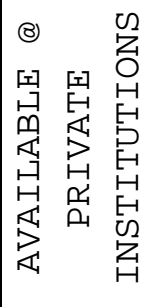 & 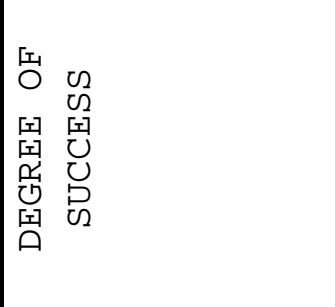 \\
\hline \multicolumn{4}{|l|}{ Food Services } \\
\hline Vending services & $100 \%$ & $87 \%$ & Successful \\
\hline Snack bar & $100 \%$ & $73 \%$ & Successful \\
\hline Full service cafeteria & $75 \%$ & $27 \%$ & Successful \\
\hline Charge cards & $88 \%$ & $33 \%$ & Successful \\
\hline \multicolumn{4}{|l|}{ Orientation Services } \\
\hline Continuous Orientation & $13 \%$ & $33 \%$ & Successful \\
\hline General Orientation & $25 \%$ & $67 \%$ & Successful \\
\hline Peer Advising Program & $13 \%$ & $20 \%$ & Successful \\
\hline \multicolumn{4}{|l|}{ College Personnel } \\
\hline Administrators with experience & $50 \%$ & $100 \%$ & Successful \\
\hline Faculty with experience & $63 \%$ & $93 \%$ & Successful \\
\hline Administrators are trained & $50 \%$ & $73 \%$ & Successful \\
\hline \multicolumn{4}{|l|}{ Registration } \\
\hline Registration assistance & $63 \%$ & $93 \%$ & Successful \\
\hline Pre-registration & $88 \%$ & $93 \%$ & Successful \\
\hline Registration by mail & $50 \%$ & $60 \%$ & Successful \\
\hline Registration by phone & $63 \%$ & $27 \%$ & Successful \\
\hline Registration by e-mail & $29 \%$ & $7 \%$ & Successful \\
\hline Access to office & $38 \%$ & $13 \%$ & Successful \\
\hline Access via computer & $100 \%$ & $21 \%$ & Successful \\
\hline \multicolumn{4}{|c|}{ Student Activities for Adult Students } \\
\hline Student organization(s) & $50 \%$ & $64 \%$ & Successful \\
\hline Rec. facilities in evening & $75 \%$ & $86 \%$ & Successful \\
\hline Rec. facilities for family & $63 \%$ & $73 \%$ & Successful \\
\hline Student governance & $75 \%$ & $64 \%$ & Not Successful \\
\hline Cultural activities & $100 \%$ & $93 \%$ & Successful \\
\hline
\end{tabular}


Table 80 Continued...

Population Summary: Availability and Degree of Success for $\underline{\text { Student Services }}$

\begin{tabular}{|c|c|c|c|}
\hline STUDENT SERVICE & 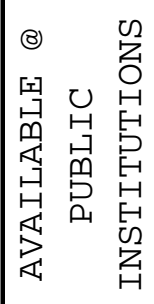 & 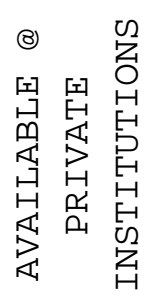 & 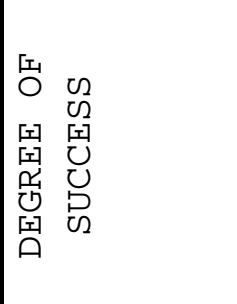 \\
\hline \multicolumn{4}{|l|}{ Educational Support Services } \\
\hline Disabled student services & $100 \%$ & $93 \%$ & Successful \\
\hline Tutoring & $75 \%$ & $93 \%$ & Successful \\
\hline Study skills workshops & $100 \%$ & $93 \%$ & Successful \\
\hline Library use workshops & $100 \div$ & $100 \%$ & Successful \\
\hline Library facility open & $100 \%$ & $87 \%$ & Successful \\
\hline Time management workshops & $100 \%$ & $73 \%$ & Successful \\
\hline Student lounge & $100 \%$ & $87 \%$ & Successful \\
\hline Study areas & $86 \%$ & $87 \%$ & Successful \\
\hline Computer lab & $100 \%$ & $100 \%$ & Successful \\
\hline Security lockers & $57 \%$ & $47 \%$ & Successful \\
\hline Centralized locations & $63 \%$ & $47 \%$ & Successful \\
\hline \multicolumn{4}{|l|}{ Residential Life Services } \\
\hline Overnight/Weekend housing & $25 \%$ & $40 \%$ & Successful \\
\hline Residential staff trained & $50 \%$ & $33 \%$ & Successful \\
\hline \multicolumn{4}{|l|}{ Parking \& Transportation } \\
\hline Bus service & $63 \%$ & $29 \%$ & Successful \\
\hline Adequate/well-lighted parking & $87 \%$ & $100 \%$ & Successful \\
\hline Security personnel & $100 \%$ & $87 \%$ & Successful \\
\hline \multicolumn{4}{|l|}{ Miscellaneous } \\
\hline Student health services & $100 \%$ & $40 \%$ & Successful \\
\hline Child care services & $38 \%$ & $20 \%$ & Successful \\
\hline Child care referral services & $50 \%$ & $20 \%$ & Successful \\
\hline
\end{tabular}




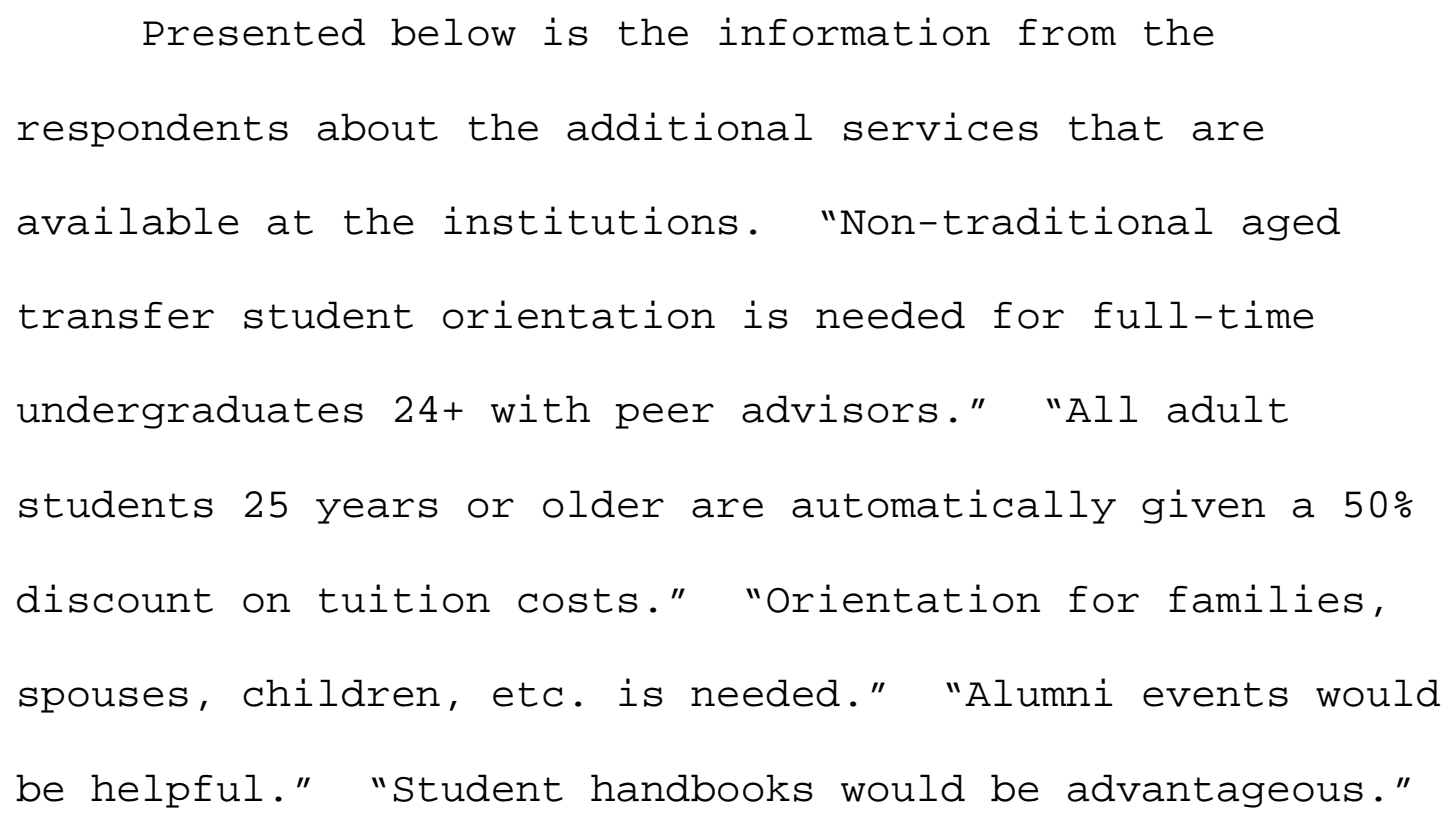


Conclusions and Recommendations

Admissions Services

Shriberg (1984) stated that if institutions want to attract adult students, they must recruit them and offer appropriate kinds of services and a system of evaluation that reflects the adult-student life status. Colleges must send recruiters to the locations where the adult students are, such as places of employment, G.E.D. programs and community colleges. Cohen (1980) suggested that adults might never enter the higher education arena if they face obstacles during the admissions process. Previous work experience and/or training must be recognized as being important; adult students must encounter flexibility in receiving credit for such out-of-college experiences. These students want to know that they are welcome at the institution, what is expected of them once they enroll, and how much it will cost.

Shriberg (1984) declared that admissions services include the following: maintaining an open admissions office during hours that are convenient to the varying schedules of adult students; providing advanced academic standing for work experience or other training; direct recruitment of adults; scheduling personnel recruitment 
visits in local schools and businesses with adult students; easing the entry experience by adult students.

In this study, involving colleges and universities in Virginia, the public and private institutions share similar results for two services: ability to apply for a part-time degree and access to admission information via the computer. Services provided by the private institutions include special recruitment materials, direct recruitment of adults, advanced credit for work/training experience, the ability to apply for part-time degree programs, admissions office open during evenings, and admissions information available via the computer. The public institutions provide five of the eight admissions' services, which include: the direct recruitment of adults, personnel recruitment visits, advanced credit for work/training experience, ability to apply for part-time degree programs, and admissions information via the computer.

Admissions services is the only category in which the respondents from both public and private institutions gave an overall success rating of "very successful" to a service. Those services included: advanced credit for work/training experience, ability to apply for part-time 
degree programs, and admissions office open during the evenings.

When the findings of this study are compared to the needs of adult students identified in the literature, it can be concluded that the private institutions in Virginia provide admissions services that adequately respond to the needs of their adult student populations. It is recommended, however, that in order to fully meet the adult students' needs at their colleges, the institutions must explore the feasibility of offering advanced academic credit for work/training experience and the service of personnel recruitment visits better tailored to adults. Public institutions should work to develop recruitment materials directed specifically toward the adult student population, devise special admission criteria that recognize the value of work and training experience, and maintain office hours that are conducive to adult students' schedules. Business Office Services

Richter-Antion (1986) found that financial concerns are one of the primary considerations that impact on the adult student experience. Adult students are responsible for themselves and often, are also directly responsible for the well being of others. Therefore, they must continue to 
support themselves and their families financially. A hardship can be placed on adult students and their families when the institution requires full tuition payment at the beginning of the semester. According to Shriberg (1984), even with company reimbursement plans, credit arrangements may be necessary since most plans only reimburse at the end of the semester. As a result, the policy of paying the entire tuition fee at the beginning of the semester could result in adult students not being able to enter the college or university because they cannot pay the full tuition in one payment. The availability of tuition installment plans at the public and private institutions, therefore, is important for facilitating more students in entering the college or university.

The data indicate that tuition installment plans are available at the majority of both public and private institutions in Virginia and are considered by administrators as "successful" in attracting adult students.

The population's responses also indicate that access to the business office during evenings is usually not available at the public institutions. Information regarding the business office via the computer is available at $50 \%$ of the public institutions. The majority of the 
private institutions offers neither access to the business office during evenings nor information via the computer.

It is recommended that the public and private institutions explore the feasibility of their business offices maintaining office hours during evenings. It is also recommended that private institutions investigate the option of providing information about the business office through their computer systems.

Counseling Services

The importance of providing an array of counseling services that assist the adult student's transition is conveyed throughout the literature. Knox (1986) found that adult students need help in building their self-confidence as students, and Thon (1984) suggested that almost all adults have fears and anxieties upon returning to the classroom. Counselors must be prepared to deal with the issues that adult students face: the aging process, financial difficulties, preparation for retirement, family problems, and many others (Shriberg, 1984). Counseling at the four-year institutions in Virginia can include academic advising, career counseling, referral to specialists, and job placement after graduation.

Adult students also need career counseling services that are available at times convenient to their busy 
schedules. Aslanian (1995) stated that 90\% of adult students reported that they returned to school because of job/career changes. As a result, the availability and access of career services are of primary importance. The career counselors at the institutions must be prepared to work with people who are at the mid-career or even preretirement stages of their careers (Shriberg, 1984).

The data show that all services listed in the category of counseling are available at the majority of both public and private institutions. In particular, the data show that $50 \%$ of the public institutions provide career counseling services directly designed for adult students, whereas approximately 70\% of the private institutions offer services for their adult students. However, more public institutions provide access to the services via the computer.

It is recommended that public institutions work to promote their career counseling services and maintain office hours more conducive to the schedules of the adult students.

\section{Financial Aid}

Financial aid services are defined as the administrative and counseling services designed to help students obtain necessary funds for college. Aid generally 
comes in the form of loans, scholarships, grants, and workstudy programs.

The financial aid application process, traditionally, is a difficult one. Understanding the availability and eligibility requirements of financial aid programs and completing the forms can be very discouraging for all students. Also, adult students may assume that because of their age or stage in life, they will not be able to qualify for the financial assistance they need to pursue their educational goals. A decade ago, this might have been accurate; however, many agencies have now established funding programs specifically for reentry, midlife, or older students. Colleges have also created tuition reduction programs for this population (Schlachter, 1995). In addition to the institutional tuition and fees, adult students need money to pay living expenses and to accommodate for at least some of the income they might forfeit by returning to college. The financial aid needs of these students are made more critical by the fact that they often have families to support. Solmon and Gordon (1981) found that the availability of financial aid was very important to adult students in their decision to attend a particular institution. 
Findings from this survey show that both public and private institutions provide assistance for adult students in completing financial aid forms and that this service is successful. In addition, public institutions provide access to their financial aid services via the computer, while private institutions provide publications that outline financial aid programs and services for adult students.

The data indicate, however, that neither public nor private colleges have special loan or scholarship programs designed specifically for adult students. This service would provide financial aid alternatives for adult students who might otherwise fail to qualify for federal or state aid. In addition, the institutions are not maintaining office hours for the financial aid office during the evenings for the convenience of the adult students.

It is recommended that the four-year colleges in Virginia develop loan and scholarship programs designed specifically for adult students who may not qualify for state and federal financial aid. They should also maintain office hours more conducive to the professional and/or parental schedules of adult students. 
Food Services

Payette (1980) stated that food services can play an important role in providing a satisfactory environment for adult students. A major complaint of the adult population on many campuses is that snack bars are the only food service still open to meet their on-campus dining needs. Given that many students arrive for classes at times when the cafeterias are closed or may be located far from the classrooms, the availability of snack bars and vending machines is very important to the students. Adult students, in particular, who have classes in the evening may have come to school directly from work and have not had the opportunity to have dinner. The food services provided by the institution are often the only option for a student to obtain food prior to a class. Most campuses have the ability to develop some flexibility in the meal system and hours of operations (Payette, 1980).

At the public institutions in the Commonwealth of Virginia, the food services of vending machines, snack bars, full-service cafeterias open during evenings, and charge cards are all available to the adult student population, and they are rated by the administrators as "successful" in attracting adult students. At the private institutions, only the services of vending machines and 
snack bars are available. The majority of these institutions does not offer full-service cafeterias in the evening or charge cards for student use.

It is recommended that private institutions explore the advancement of full-service cafeterias which are operated at hours convenient to the adult student population. Orientation Services

Pascarella \& Terenzini (1991) found that orientation programs serve an important early socialization function. These programs help students adjust to the intellectual and social norms of the institution. In addition, introducing students to available support services, key administrators, student social life, and major and degree requirements, as well as their early course registration, are important factors in facilitating the students' adjustment to the institutions.

Administrators also realize that the most effective orientation programs are not limited to the first few days or weeks of the first semester. Apps (1978) stated that many adult students experience feelings of isolation and, to compensate, opportunities should be provided that allow them to meet and interact with other returning adult students. It is important for institutions to afford the 
adult students an opportunity to become familiar with the institution and with their peers.

Findings from this survey show that public institutions do not provide the orientation services as identified in the survey (see Table 80 for a list of services). Further, the private institutions provide only a general orientation program for adult students and not the services of continuous orientation and peer advising; however, the general orientation program was judged "successful" in attracting adult students by the administrators.

The responses of the population suggest that the fouryear colleges in Virginia do not provide adequate orientation services to their adult students. It is therefore recommended that student affairs officers at both public and private institutions consider the merits of establishing continuous adult student orientation and peer advising programs to contribute to the transition and support of their adult students. College Personnel

Adult students often enter the classroom with a variety of concerns and needs that must be acknowledged and addressed. Adults prefer faculty members to employ an individual approach to instruction; to evaluate course 
progress on more than tests alone; and to use alternate methods of meeting course requirements. Adult students also prefer professors and instructors who are interested in the individual student's progress, who are relaxed and informal in class, who use many examples, and who have a realistic view of the student's outside duties and responsibilities (Knox, 1986).

The importance of having student affairs staff who understand and are experienced in working with adults is undeniable. According to Rentz and Saddlemire (1988), the well-being and retention of the adult student is closely tied to the successful efforts of the professional student affairs staff to help the institution make the necessary changes to fit the needs of the adult student population.

The responses from this survey indicate that both institutional types have faculty and administrators who are experienced in working with adult students, although the private institutions have a higher percentage rate for availability than do the public institutions.

It is recommended that public institutions explore the feasibility of providing additional training to the administrators and staff regarding the needs of their adult student population. 
$\underline{\text { Registration Services }}$

Completing the registration process can be time-

consuming and confusing. All students, but adults in

particular, prefer quick and simplified registration

procedures that also can be completed during the evening

and/or weekends. Often, several administrative signatures

are required for registration, and the individuals whose

signatures are needed may have few office hours or only day

hours available. Registration should be made more

convenient for adults who often find it difficult to take

time off during a work day (Shriberg, 1984).

The data from this study show that pre-registration services, registration assistance, and registration by mail are available at the majority of both public and private institutions and are considered "successful" in attracting adult students by the respondents.

The services of registration by phone and access to information via the computer are available at the public institutions but not at the private institutions. The services of registration by e-mail and access to the registration office during evenings are not available at the majority of both public and private institutions.

Given the importance of the registration process in a student's life, it is imperative that administrators strive 
to facilitate the procedure for scheduling classes. It is thus recommended that private institutions investigate the options of registering for classes via the phone and email. They also should develop information on the computer so that adult students may educate themselves about the required procedures. Public institutions should explore the development of registering for classes via e-mail. In addition, it is recommended that they examine the option of maintaining office hours that are more conducive to the adult students' time constraints. Student Activities for Adult Students

The student activities programmer on campuses is in an excellent position to help the campus modify its environment for the adult student. The student handbook and organizational directories should include material on facilities' renting, escort services, child care centers, and support groups both on campus and in the adjoining community. Program publicity must go beyond the residence halls to the classrooms, parking lots, commuter mailboxes and home mailboxes (Rentz \& Saddlemire, 1988).

The findings from this study indicate that the population provides all student activities as identified in the survey (see Table 80 for a list of these activities). However, administrators rate the service of student 
governance opportunities as "not successful" in attracting adult students. This was the only service in the survey that received this rating.

Public and private institutions should investigate the reasons why student governance is not successful in attracting adult students or in helping meet their needs. Educational support Services

A substantial number of the educational support services listed on the survey are currently available to adult students. The majority of the population identified services that directly contribute to the educational success of the student. According to Cohen (1980) educational support services are crucial to the success of adult students because at some point in a student's academic career, he or she will likely recognize skill inadequacies. They may be unsure about how to take lecture notes, study effectively, and locate study materials in the library .

A majority of public institutions offer all services identified in the survey. The institutions report that seven of the eleven services were offered at $100 \%$ of the institutions.

Private institutions offer nine of the eleven educational support services at their institutions. The 
services of security lockers available for the storage of personal and class items, and classes conducted at centralized locations off-campus, are offered at only 47\% of the institutions.

It is recommended that the remaining private institutions research the possibility of providing security lockers for their students. These institutions should also investigate the feasibility of conducting classes at centralized locations off-campus.

$\underline{\text { Residential Life Services }}$

Residential life professionals have long recognized the special needs of various populations of students, and higher education institutions have responded with a variety of housing arrangements designed to meet those needs (Cohen, 1980). Adult students need more innovative housing arrangements which take into consideration the need for privacy and family relationships (Shriberg, 1984). Rentz and Saddlemire (1988) found that special skills and additional training are necessary for the residence staff members to perform their jobs effectively.

Fifty percent of the public colleges have staff members trained to work with adult students but the majority do not provide overnight/ weekend accommodations. 
Only 25\% of the public institutions offer flexible housing arrangements .

The majority of private institutions do not offer services in the category of residential life. Only $40 \%$ of the schools offer overnight/weekend accommodations and 33\% have staff who are trained in adult students' needs.

It is recommended that the public and private institutions explore the development of residential accommodations which have the flexibility that adult students need and provide training to the residential life staff regarding the needs and issues of adult students. Parking \& Transportation Services

The most obvious concerns faced by adult students who do not live on the campus, are those related to transportation to campus. In particular, the availability of parking and bus service (if the parking lot is a distance from the buildings) is very important. For adult students who are significantly older, parking is also of great concern. Parking areas should be protected and convenient to the classroom buildings. Faculty parking areas, usually located close to the buildings, should be available to those pre-retired or retired students who may be older than their professors and thus have an obvious need for close parking (Shriberg, 1984). 
The majority of public institutions provide all parking and transportation services identified in the survey. The private institutions provide only the service of security personnel at the majority of their institutions. The respondents at the private institutions indicate that adequate and well-lighted parking is not available at any of their institutions. Bus service is available at only 29\% of the private colleges.

It is recommended that private institutions research the possibility of bus service in locations where classes are a substantial distance from the parking areas. In particular, private institutions must explore the option of adequate and well-lighted parking at each institution. Miscellaneous Services

Child care problems affect student access to education, and the institutions that take steps to offer child care services gain several advantages. These services can remove possible barriers for students which can affect their course of study, time and attention to study, attendance and even the option to attend school at all. Child care programs are also powerful recruitment tools, have positive impacts on institutional morale and affirmative action goals, attract favorable media and 
public attention, and present a desirable image to potential donors (California State University, 1984). Students enrolled at four-year colleges and universities in the United States are traditionally afforded some type of health care from institutional student health programs or through group health plans (Shriberg, 1984).

All respondents at the public institutions report that student health services are available for their adult students. Only 40\% of the respondents at the private institutions relate that these services are provided.

In regard to the survey item considering child care services, the majority of public institutions provide child care referrals but do not offer the actual child care services. The majority of private institutions provide neither child care referrals nor actual child care services.

Both public and private institutions might find it beneficial to investigate the establishment or enhancement of child care services for their students. In addition, private institutions should explore available options regarding health care for their adult students. 


\section{Directions for Further Investigations}

Based on this study, three areas are suggested for further study. First, adult students at the public and private undergraduate institutions should be surveyed and their responses compared with those of the administrators. In order for student services to be truly effective, the students must be involved in examining the efficacy of the student services.

Second, there exists a need to explore in greater detail the degree of success in attracting adult students to the student services. Reasons why administrators evaluated each student service to be successful or not successful could be investigated. Understanding the criteria they use to make their assessments would be beneficial in appraising and modifying their policies to meet the needs of the adult student population. Third, given the projected advances in technology, there is a need to investigate the effect "Virtual Universities" will have on adult students and, therefore, student services. The adult student population is the ideal clientele for understanding the advantages of longdistance education. Administrators must anticipate and 
prepare for the changing technologies and their ramifications on student services.

\section{Summary}

This chapter has offered an interpretation of the data presented in Chapter Four. It has (1) presented a review of the purpose and rationale for the study, (2) explained the data discussed in Chapter Four relative to the literature, (3) presented the conclusions for each category of student services, (4) offered recommendations for the study institutions, and (5) presented recommendations for further studies.

The study, itself, has fulfilled its purpose, that of investigating the student services currently available at Virginia's four-year public and private institutions, determining which of the available services are considered successful or not successful in attracting adult students, and ascertaining if there are additional services that are needed to accommodate adult students. 
References 
REFERENCES

Ackell, E. F., Epps, R. G., Sharp, N. A., \& Sparks, H. L. (1986). Adapting the university to adult students: a developmental perspective. In William H. Warren (Ed.), Commission on Higher Education and the Adult Learner.

Washington, D. C.: The American Council on Education.

American College Personnel Association (ACPA). (1994). The student learning imperative: Implications for student affairs. Washington, DC: Author.

Apps, J. W. (1981). The adult learner on campus: A guide for instructors and administrators. Chicago: Follett Publishing Co.

Aslanian, C. B. (1995). Planning for the students of tomorrow. Catalyst, $25(1), \mathrm{p} .5-7$.

Aslanian, C. B. \& Brickell, H. M. (1988) . How Americans in transition study for college credit. New York: College Entrance Examination Board.

Baker, R. W. (1991). Student personnel services for adult students at Virginia community colleges. Dissertation. Charlottesville, VA: University of Virginia.

Bean, J. P. \& Metzner, B. S. (1985). A conceptual model of nontraditional undergraduate student attrition. Review of Educational Research, 55, p. 485-540.

Benshoff, J. M. (1991). Nontraditional colleges students: A developmental look at the needs of women and men 
returning to school. Journal of Young Adulthood and Middle Age, 3, 47-61.

Benshoff, J. M. \& Lewis, H. A. (1992). Nontraditional college students. ERIC Reproduction Number ED 347483.

Bloland, P. A., Stamatkos, L. C. \& Rogers, R. R. (March/April, 1996). Redirecting the role of students affairs to focus on student learning. Journal of College Student Development, $37(2)$, p. 217-227.

Brown, C. D. \& Linnemann, R. E. (1995). Services for adult undergraduate students in a four-year college. The Journal of Continuing Higher Education, 43(2), p. 2-13. Brubacher, J. S. \& Rudy, W. (1976). Higher education in transition: A history of American colleges and universities, 1636-1976. New York: Harper \& Row Publishers, Incorporated.

California State University. (1984). Study of the need for child care services. ERIC Document Reproduction Service No. ED 301347

Caple, R. B. (March/April, 1996). The learning debate: A historical perspective. Journal of College Student Development, $37(2)$, p. 193-201.

Chickering, A. W. \& Havighurst, R. J. (1981). The life cycle. In A. W. Chickering \& Associates (Eds.), The modern American college (pp. 16-54). San Francisco: Jossey-Bass Publishing 
Chronicle of Higher Education. (1997, August 29) Almanac. $44(1), p \cdot 10 \& 18$.

Cohen, R. D. (1980). "Assisting the adult learning in settling-in." In Arthur Shriberg (Ed.) Providing student services for the adult learner. San Francisco: Jossey-Bass, New Directions for Student Services \#11.

Cohen, A. M. \& Brawer, F. B. (1989) 2nd Ed. The American community college. San Francisco: Jossey-Bass Publishers.

Cowley, W. H. (1949). Student development in higher education:theories, practices, and future directions. Washington D.C.: American College Personnel Association. Crouch, R. T. (May/June, 1995). Realities of a new demographic ball game. Adult Learning. P. 25-26.

Cross, K. P. (1980). Our Changing students and their impact on colleges: Prospects for a true learning society. Phi Delta Kappan, May, 630-632.

Cross, K. P. (1981). Adults as learners. San Francisco: Jossey-Bass Publishing.

Cross, K. P. (1987). Adults as learners: Increasing participation and facilitating learning. San Francisco: Jossey-Bass Publishing.

El-Khawas, E. (1996). "Student diversity on today's campuses" in Susan R. Komives (Ed). Student services: a 
handbook for the profession. p. 64-80. San Francisco: Jossey-Bass .

Fenske, R. H. (1989). Evolution of the student services profession. In Ursula R. Delworth et al. (Eds) Student services: A Handbook for the profession. 2nd edition. San Francisco: Jossey-Bass.

Garland, P. H. \& Grace, T. W. (1993). New perspectives for student affairs professionals: evolving realities, responsibilities and roles. ASHE-ERIC Higher Education Report No. 7. Washington D.C.: The George Washington University •

Gerald, D. E. \& Hussar, W. J. (1995). Projections of education statistics to 2005. National Center for Education Statistics. ERIC Reproduction Service No. ED 379347

Gifford, B. R. (1992, August 26). Coming back to campus. The Chronicle of Higher Education, p. A12.

Greenland, A. E. (1988) Responsiveness to adult undergraduates in a traditional land-grant university: An institution-wide assessment. Amherst, MA: University of Massachusetts. ERIC Document Reproduction Service No. ED 302 105 .

Grottkau, B. J. \& Davis, J. L. (1987). Supportive services for returning women students: Will higher education meet the challenge? Journal of the National Association of Women Deans, Administrators, and Counselors, $50(4), 8-15$. 
Houle, C. O. (1961). The inquiring mind. Madison: University of Wisconsin Press.

Jacoby, B. (1989, January 19). "Colleges must do more to enhance the education of commuter students." The Chronicle of Higher Education.p. A5

Jacoby, B. (1993). Today's students: Diverse needs require comprehensive responses. In T. K. Miller \& R. B. Winston (Eds.) Administration and leadership in student affairs. Muncie, IN: Accelerated Development Inc.

Kasworm, C. F. (1980). Student services for the older undergraduate student. Journal of College Student Personnel, 21, p. 163-169.

Knowles, M. S. and Associates (1984). Andragogy in action. San Francisco: Jossey-Bass.

Knox, A. B. (1986). Helping adults learn. San Francisco: Jossey-Bass.

Liveright, A. A. \& Haygood, N. (Eds.). (1969). The Exeter Papers. Chicago: Center for the Study of Liberal Education for Adults.

Merriam, S. B. \& Caffarella, R. S. (1991). Learning in adulthood. San Francisco: Jossey-Bass.

Miller, T. K. \& Prince, J. S. (1976). The future of student affairs. San Francisco: Jossey-Bass. 
Miller, T. K. \& Winston, R. B. (1991). Administration and leadership in student affairs: actualizing student development in higher education. Muncie, IN: Accelerated Development.

Mishler, C. Fredrich, D. Hogan, T. P. \& Woody (1982). Adult students: pace toward graduation. College and University, $58(1)$, p. 31-41.

Muench, K. E. (1987). A comparative study of the psychosocial needs of adult men and women students in an adult degree program. ERIC Reproduction Number ED 287020 Naylor, M. (1988). Preventing obsolescence through adult retraining. (ERIC Digest No. 72). Columbus, OH: ERIC Clearinghouse of Adult Career, and Vocational Education.

Neal, A. L. (1985). A study of perceived needs of traditional and non-traditional students for selected student personnel services. Unpublished doctoral dissertation, Vanderbilt University, Nashville, TN. Pascarella, E. T. \& Terenzini, P. T. (1991). How college affects students. San Francisco: Jossey-Bass. Payette, D. L. (1980). "The adult learner and student programming." In Arthur Shriberg (Ed.) Providing student services for the adult learner. San Francisco: Jossey-Bass, New Directions for Student Services \#11. 
O'Connor, P. J. (1994). The needs of adult university students: a case study. College and University, 69(2), 8486.

Okun, M. A., Taub, J. B., \& Witter, R. A. (1986). Age and sex differences in negative life events and student usage. Journal of College Student Personnel, 27, p. 160-165. Rentz, A. L. \& Saddlemire, G. L. (Eds) (1988). Student affairs functions in higher education. Springfield, IL: Charles C.Thomas Publisher.

Richter-Antion, D. (1986) . Qualitative differences between adult and younger students. NASPA Journal, 23, p. $58-62$.

Rubenson, K. (1989). The sociology of adult education. In Merriam, S. B. \& Cunningham, P. M. (Eds) Handbook of Adult and Continuing Education. San Francisco: Jossey-Bass. Sanford, N. (1967). Where colleges fail: a study of the student as a person. San Francisco: Jossey-Bass.

Schlachter, G.A. (1995). The Back-to-school money book 1996-1998). A financial guide for midlife and older women seeking education and training. American Association of Retired Persons. ERIC Reproduction Service No. ED 409468. Schlossberg, N. K., Lynch, A. Q., \& Chickering, A. W. (1989) . Improving higher education environments for adults. San Francisco: Jossey-Bass. 
SCHEV. (1998) SCHEV research data: Enrollment summaries by age. [On-line]. Available: http://www.schev.edu/wuresrch/index.html. [1998, April 2]

SCHEV. (1997a). Senior public colleges and universities. Richmond, VA: SCHEV.

SCHEV (1997b). Private not-for-profit institutions of higher education. Richmond, VA: SCHEV.

Shearon, R. W. \& Tollefson, T. A. (1989). "Community Colleges." In Sharon B. Merriam and Phyllis M. Cunningham (Eds.) - Handbook of adult and continuing education. p. 316-331. San Francisco: Jossey-Bass.

Sheehan, E. P., McMenamin, N. \& McDevitt, T. M. (1992). Learning styles of traditional and nontraditional university students. College Student Journal, 26(4), p. 486-490.

Shipp, T. \& McKenzie, L. R. (1981). Adult learners and non-learners: Demographic characteristics as an indicator of psychographic characteristics. Adult Education, 31(4). p. $187-198$.

Shriberg, A. (Spring, 1984) A self-audit: Preparing for the adult learner. NASPA Journal, 21, 24-27.

Snyder, T. D. (1988). Digest of education statistics, 1988. National Center for Education Statistics (Stock No. 065-000-00-351-1). Washington, DC: U. S. Government Printing Office. 
Solmon, L. C. \& Gordon, J. J. (1981). The

characteristics and needs of adults in postsecondary

education. Lexington, MA: Lexington Books.

Spratt, P. A. (Spring, 1984) Needs and interests of

adult learners: what do they seek on a campus? NASPA

Journal, 21, 4-7.

Terrell, P. S. (1990). Adapting institutions of higher education to serve adult students' needs. NASPA Journal, 27, $241-247$

Thiel, K. K. (1984). The gap between needs and

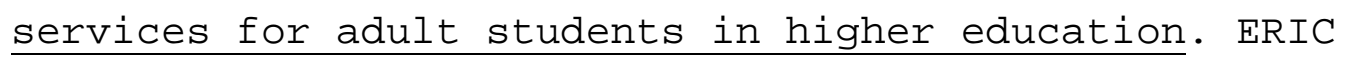

Document Reproduction Service No. ED 251619.

Thon, A. J. (Spring, 1984). Responding to the nonacademic needs of adult students. NASPA Journal, 21, 2835.

U.S. Bureau of the Census. (1982). General population characteristics for Virginia. Series P-48 Population

Surveys. Washington, D. C.: U.S. Government Printing Office.

U.S. Bureau of the Census. (1992). General population characteristics for Virginia. Series I-48 Population

Surveys. Washington, D. C.: U.S. Government Printing Office.

Watkins, B. T. (1989, May 17). Centers for retirees flourish as higher education courts the expanding market of older adults. Chronicle of Higher Education, 35 (36) A1, A36. 
APPENDICES 
Appendix A: The Population in the Study 
THE POPULATION IN THE STUDY

PUBLIC INSTITUTIONS

1. Dr. Maurice J. O'Connell

Dean of Students

Christopher Newport University

Newport News, VA 23606-2298

2. Dr. Gary Juhan

Vice Chancellor for Student Affairs

Clinch Valley College

Wise, VA 24293

3. Dr. W. Samuel Sadler

Vice President, Student Affairs

College of William \& Mary

Williamsburg, VA 23185

4. Dr. Karen Rosenblum

Vice President, University Life

George Mason University

Fairfax, VA 22030-4444

5. Dr. Al Menard

Associate VP for student Affairs

James Madison University

Harrisonburg, VA 22807

6. Ms. Phyllis Mable

Vice President, Student Affairs

Longwood College

Farmville, VA 23909

7. Dr. Bernard M. Chirico

Vice President, Student Affairs and Dean of Students

Mary Washington College

Fredericksburg, VA 22401-5358

8. Dr. James W. Satterfield

Vice President, Student Affairs

Norfolk State University

Norfolk, VA 23504 
9. Dr. Dana D. Burnett

Vice President, Student Services and Dean of Students Old Dominion University

Norfolk, VA 23526

10. Dr. Paul W. Harris

Vice President, Student Affairs

Radford University

Radford, VA 24142

11. Dr. Shamin Sisson

Associate Dean of Students

University of Virginia

Charlottesville, VA 22903

12. Dr. Henry G. Rhone

Vice Provost for Student Affairs

Virginia Commonwealth University

Richmond, VA 23284-3017

13. Col. James N. Joyner, Jr.

Director of Cadet Affairs

Virginia Military Institute

Lexington, VA 24450

14. Dr. Landrum L. Cross

Vice President, Student Affairs

Virginia Polytechnic Institute and State University Blacksburg, VA 24061

15. Dr. Claud Flythe

Chief of Staff and Vice President, Student Affairs

Virginia state University

Petersburg, VA 23801 


\section{PRIVATE INSTITUTIONS}

1. Dr. Patt Morgan

Dean of Student Development

Averett College

Danville, VA 24541

2. Mr. Kenneth R. Forrest

Acting Dean of Students

Bluefield College

Bluefield, VA 24605

3. Dr. William D. Miracle

Dean for Student Development

Bridgewater College

Bridgewater, VA 22812

4. Ms. Connie Marshner

Director, Student Affairs

Christendom College

Front Royal, VA 22630

5. Dr. Eldon Nelson

Dean of Student Services

College of Health Sciences

Roanoke, VA 24031-3186

6. Ms. Patti S. Helton

Vice President, Student Life

Eastern Mennonite University

Harrisonburg, VA 22801

7. Mr. Anthony Campbell

Dean of Students

Emory and Henry College

Emory, VA 24327-0947

8. Mr. Peter Lefferts

Vice President, Student Affairs

Ferrum College

Ferrum, VA 24088

9. Mr. Lewis H. Drew

Dean of Students

Hampden-Sydney College

Hampden-Sydney, VA 23943 
10. Dr. Rodney D. Smith

Vice President, Student Affairs

Hampton University

Hampton, VA 23668

11. Ms. Renee C. Romano

Vice President, Student Services

Hollins College

Roanoke, VA 24020

12. Mr. Mark L. Hine

Vice President, Student Development

Liberty University

Lynchburg, VA 24506

13. Mr. John G. Eccles

Dean of Students

Lynchburg College

Lynchburg, VA 24501-3199

14. Dr. Heather Wilson

Dean of Students

Mary Baldwin University

Staunton, VA 24401

15. Ms. Linda R. McMahon

Vice President, Student Services and Dean of Students Marymount University

Arlington, VA 22207

16. Mr. Ira L. Andrews III

Dean of Students

Randolph-Macon College

Ashland, VA 23005

17. Ms. Donnie A. Morgan

Dean of Students

Randolph-Macon Woman's College

Lynchburg, VA 24503-1526

18. Mr. Mc Millan H. Johnson

Vice President, Student Affairs and Dean of Students Roanoke College

Salem, VA 24153 
19. Mr. Harley Knowles

Dean of Student Programs

Shenandoah University

Winchester, VA 22601

20. Mr. Toby Anderson

Dean of Students

Southern Virginia College

Buena Vista, VA 24416

21. Ms. Susan Iverson

Dean of Students

Sweet Briar College

Sweet Briar, VA 24595

22. Mr. Leonard S. Goldburg

Vice President, Student Affairs

University of Richmond

Richmond, VA 23173

23. Dr. Bruce Storey

Vice President of Student Development and Admissions

Virginia Intermont College

Bristol, VA 24201

24. Mr. Wilbert Talley

Vice President of Student Affairs \& University Pastor

Virginia Union University

Richmond, VA 23220-1790

25. Dr. David E. Buckingham

Vice President of Student Affairs and Dean of Students Virginia Wesleyan College

Norfolk, VA 23502-5599

26. Mr. David L. Howison

Dean of Students

Washington and Lee University

Lexington, VA 24450-0303

27. Dr. Kathy Franklin

Dean of Liberal Arts and Sciences

Virginia University of Lynchburg

Lynchburg, VA 24501 
Appendix B: The Survey Instrument 


\section{STUDENT SERVICES FOR ADULT UNDERGRADUATE STUDENTS}

The purpose of this questionnaire is to determine the availability of student services for adult undergraduate students at your institution and the extent to which the services are considered successful. Definition of Adult Student: an individual who is at least 25 years of age and who is enrolled in either full- or part-time course work in any program at your institution. Please circle the appropriate response to the following items and indicate if the services is Available (Yes) or Not Available (NO). If Yes, is the service Very Successful (VS), Successful (S), or Not Successful (NS) in attracting adult students.

\begin{tabular}{|c|c|c|c|c|c|c|}
\hline \multicolumn{7}{|c|}{ Admissions } \\
\hline & & \multicolumn{2}{|c|}{$\begin{array}{l}\text { Available for } \\
\text { Adult Students }\end{array}$} & \multicolumn{3}{|c|}{$\begin{array}{l}\text { Success in Attracting } \\
\text { Adult Students }\end{array}$} \\
\hline 1 & Recruitment materials directed specifically to adult students & YES & $\mathrm{NO}$ & VS & $\mathrm{S}$ & NS \\
\hline 2 & Direct recruitment of adult students & YES & NO & VS & $S$ & NS \\
\hline 3 & Personnel recruitment visits with prospective adult students & YES & $\mathrm{NO}$ & VS & $\mathrm{S}$ & NS \\
\hline 4 & Special admissions criteria for adult students & YES & NO & VS & $\mathrm{S}$ & NS \\
\hline 5 & Provision of advanced academic standing for work experience or training & YES & NO & VS & $\mathrm{S}$ & NS \\
\hline 6 & Ability to apply for a part-time degree program & YES & NO & VS & $\mathrm{S}$ & NS \\
\hline 7 & Access to the Admissions office during evenings & YES & NO & VS & $\mathrm{S}$ & NS \\
\hline 8 & Access to information via computer with the Admissions office & YES & NO & VS & $\mathrm{S}$ & NS \\
\hline \multicolumn{7}{|c|}{$\begin{array}{ll} & \text { Business Office } \\
\end{array}$} \\
\hline 9 & Tuition installment plans & YES & $\mathrm{NO}$ & VS & $\mathrm{S}$ & NS \\
\hline 10 & Access to the Business office during evenings & YES & NO & VS & $\mathrm{S}$ & NS \\
\hline 11 & Access to information via computer with the Business office & YES & $\mathrm{NO}$ & VS & $\mathrm{S}$ & NS \\
\hline \multicolumn{7}{|c|}{ Counseling } \\
\hline 12 & Academic Advising & YES & NO & VS & $\mathrm{S}$ & NS \\
\hline 13 & Career Counseling and Development specifically for adult students & YES & NO & VS & $\mathrm{S}$ & NS \\
\hline 14 & Referral to specialists for adults needing special services & YES & NO & VS & $\mathrm{S}$ & NS \\
\hline 15 & Counseling with training in adult student issues & YES & NO & VS & $\mathrm{S}$ & NS \\
\hline 16 & Post graduation job placement services & YES & NO & VS & $S$ & NS \\
\hline 17 & Access to career counseling services during evenings & YES & NO & VS & $S$ & NS \\
\hline 18 & Access to information via the computer for the counseling services & YES & NO & VS & $\mathrm{S}$ & NS \\
\hline \multicolumn{7}{|c|}{ Financial Aid } \\
\hline 19 & Publications that outline financial aid programs and services for adult students & YES & NO & VS & $\mathrm{S}$ & NS \\
\hline 20 & Assistance for adult students in completing financial aid forms & YES & NO & VS & $\mathrm{S}$ & NS \\
\hline 21 & Loan programs designed specifically for adult students & YES & NO & VS & $\mathrm{S}$ & NS \\
\hline 22 & Scholarship programs designed specifically for adult students & YES & $\mathrm{NO}$ & VS & $\mathrm{S}$ & NS \\
\hline 23 & Access to the Financial Aid office during evenings & YES & NO & VS & $\mathrm{S}$ & NS \\
\hline 24 & Access to information via computer with the Financial Aid office & YES & $\mathrm{NO}$ & VS & $S$ & NS \\
\hline \multicolumn{7}{|c|}{ Food Services } \\
\hline 25 & Vending area open during evenings and weekends & YES & $\mathrm{NO}$ & VS & $\mathrm{S}$ & NS \\
\hline 26 & Snack bar open during evenings and weekends & YES & $\mathrm{NO}$ & VS & $\mathrm{S}$ & NS \\
\hline 27 & Full service cafeteria open during evenings & YES & NO & VS & $\mathrm{S}$ & NS \\
\hline 28 & Charge cards available for convenience & YES & NO & VS & $\mathrm{S}$ & NS \\
\hline \multicolumn{7}{|c|}{ Orientation Services } \\
\hline 29 & $\begin{array}{l}\text { Continuous orientation program during the first semester directed toward adult } \\
\text { students and their needs }\end{array}$ & YES & NO & VS & $\mathrm{S}$ & NS \\
\hline 30 & General orientation program designed for adult students & YES & $\mathrm{NO}$ & VS & $\mathrm{S}$ & NS \\
\hline 31 & Peer advising program where returning adult students adv & YES & $\mathrm{NO}$ & VS & $S$ & NS \\
\hline
\end{tabular}




\section{STUDENT SERVICES FOR ADULT UNDERGRADUATE STUDENTS}

\begin{tabular}{|c|c|c|c|c|c|c|}
\hline \multicolumn{7}{|c|}{ College Personnel } \\
\hline & & \multicolumn{2}{|c|}{$\begin{array}{l}\text { Available for } \\
\text { Adult Students }\end{array}$} & \multicolumn{3}{|c|}{$\begin{array}{l}\text { Success in Attracting } \\
\text { Adult Students }\end{array}$} \\
\hline 32 & Administrators and staff who have experience working with adult students & YES & NO & VS & $\mathrm{S}$ & NS \\
\hline 33 & Faculty who have experience working with adult students & YES & $\mathrm{NO}$ & VS & $\mathrm{S}$ & NS \\
\hline 34 & $\begin{array}{l}\text { Administrators and staff trained in understanding adult development and adult } \\
\text { learning characteristics }\end{array}$ & YES & NO & VS & S & NS \\
\hline \multicolumn{7}{|c|}{ Registration } \\
\hline 35 & Registration assistance provided for adult students & YES & $\mathrm{NO}$ & VS & $\mathrm{S}$ & NS \\
\hline 36 & Pre-registration available to accommodate students & YES & NO & VS & $\mathrm{S}$ & NS \\
\hline 37 & Registration by mail & YES & $\mathrm{NO}$ & VS & $\mathrm{S}$ & NS \\
\hline 38 & Registration by phone & YES & $\mathrm{NO}$ & VS & $\mathrm{S}$ & NS \\
\hline 39 & Registration by e-mail & YES & $\mathrm{NO}$ & VS & $\mathrm{S}$ & NS \\
\hline 40 & Registrar's office open during evenings & YES & $\mathrm{NO}$ & VS & $\mathrm{S}$ & NS \\
\hline 41 & Access to information via the computer with the Registrar's Office & YES & $\mathrm{NO}$ & VS & $\mathrm{S}$ & NS \\
\hline \multicolumn{7}{|c|}{ Student Activities for Adult Students } \\
\hline 42 & Adult student organization(s) & YES & NO & VS & $\mathrm{S}$ & NS \\
\hline 43 & Recreational facilities available during evenings & YES & NO & VS & $\mathrm{S}$ & NS \\
\hline 44 & Recreational facilities available to student families & YES & NO & VS & $\mathrm{S}$ & NS \\
\hline 45 & Student governance opportunities for adult students & YES & NO & VS & $\mathrm{S}$ & NS \\
\hline 46 & Cultural activities and programs & YES & $\mathrm{NO}$ & VS & $\mathrm{S}$ & NS \\
\hline \multicolumn{7}{|c|}{ Educational Support Services } \\
\hline 47 & Disabled student services & YES & NO & VS & $S$ & NS \\
\hline 48 & Developmental students services/Tutoring & YES & NO & VS & $\mathrm{S}$ & NS \\
\hline 49 & Study skills workshops & YES & $\mathrm{NO}$ & VS & $\mathrm{S}$ & NS \\
\hline 50 & Library use workshops & YES & $\mathrm{NO}$ & VS & $\mathrm{S}$ & NS \\
\hline 51 & Library facility open and staff available at hours to accommodate adult students & YES & NO & VS & $\mathrm{S}$ & NS \\
\hline 52 & Time management workshops & YES & NO & VS & $\mathrm{S}$ & NS \\
\hline 53 & Student lounge areas available & YES & NO & VS & $\mathrm{S}$ & NS \\
\hline 54 & Study areas that are well-furnished, well-lighted and conducive to study & YES & $\mathrm{NO}$ & VS & $\mathrm{S}$ & NS \\
\hline 55 & Staff computer lab open with an adequate number of computers & YES & $\mathrm{NO}$ & VS & $\mathrm{S}$ & NS \\
\hline 56 & Security lockers available for storage of personal and class items & YES & NO & VS & $\mathrm{S}$ & NS \\
\hline 57 & Classes conducted at centralized locations off-campus & YES & $\mathrm{NO}$ & VS & $\mathrm{S}$ & NS \\
\hline \multicolumn{7}{|c|}{ Residential Life Services } \\
\hline 58 & Provision of overnight and/or weekend accommodations at reasonable cost & YES & $\mathrm{NO}$ & VS & $\mathrm{S}$ & NS \\
\hline 59 & Residential staff trained to work with adult students & YES & $\mathrm{NO}$ & VS & $\mathrm{S}$ & NS \\
\hline \multicolumn{7}{|c|}{ Parking and Transportation } \\
\hline 60 & Bus service to campus buildings from parking areas & YES & NO & VS & $\mathrm{S}$ & NS \\
\hline 61 & Adequate and well-lighted parking & YES & NO & VS & $\mathrm{S}$ & NS \\
\hline 62 & Security personnel on duty at all times & YES & NO & VS & $\mathrm{S}$ & NS \\
\hline \multicolumn{7}{|c|}{ Miscellaneous } \\
\hline 63 & Student health services & YES & $\mathrm{NO}$ & VS & $\mathrm{S}$ & NS \\
\hline 64 & Child care services & YES & $\mathrm{NO}$ & VS & $\mathrm{S}$ & NS \\
\hline 65 & Child care referral services & YES & $\mathrm{NO}$ & VS & $\mathrm{S}$ & NS \\
\hline
\end{tabular}

66 Are there any additional services for adult students which are offered at your institution?

Thank you for participating in this research project by completing this survey! If you have any questions or comments, please contact Kathryn D. Soule at (804) 979-9377(kds5e@virginia.edu). Your cooperation has been greatly 
Appendix C: List of Survey Pre-test Participants 


\author{
Pre-Test Participants \\ private institutions participated in the pre-test of the \\ survey instrument from December 9, 1997 to December 15, \\ 1997. \\ Public Institutions \\ Dr. Al Menard, Associate VP for Student Affairs \\ James Madison University \\ Dr. Shamin Sisson, Associate Dean of Students \\ University of Virginia

$$
\text { Private Institutions }
$$ \\ Dr. Heather Wilson, Dean of Students \\ Mary Baldwin University \\ Ms. Susan Iverson, Dean of Students \\ Sweet Briar College
}

Student affairs administrators from two public and two 
Appendix D: Cover Letters for the Survey 
January 12, 1998

Dear ,

I am currently conducting a research project which will describe the student affairs services that are currently available to adult undergraduate students in four-year colleges in the Commonwealth of Virginia.

This project involves the surveying of the Chief Student Affairs Officers for the four-year colleges and universities. Enclosed, you will find the survey instrument which will take about 10-15 minutes to complete. Please be assured that your responses will be held in strictest confidence and data reported from your survey will be used only in aggregated form. The survey is coded for the purpose of linking demographic information with the results and also follow-up. No individual will be identified. Upon request, you will receive a copy of the results of the survey.

Once you have completed the survey, please return it in the enclosed, self-addressed, stamped envelope. It will be helpful if you would return your completed survey by January 30, 1998. If you have any questions, please contact Kathryn Soule at 804-924-3411 (office), 804-979-9377 (home), or kds5e@virginia.edu (e-mail).

Your assistance in completing this survey and your cooperation in participating in this research project is greatly appreciated.

Sincerely,

Kathryn D. Soule

Research Associate
Annette Gibbs, Ph.D., Director

Center for the Study of Higher Education

Enclosure 
February 3, 1998

Dear ,

Recently, you received a copy of the questionnaire for student services for adult undergraduate students. This questionnaire is being used to collect data on the status of student services for adult students at the four-year public and private colleges in the Commonwealth of Virginia.

The questionnaire was sent to all Chief Student Affairs Officers at the 15 public and 30 private four-year undergraduate institutions in Virginia. As of this date, $40 \%$ of the surveys have been returned.

The purpose of this letter is to ask that you please complete and return your questionnaire. I know your schedule is hectic, however, I need your help. The research population is composed of only 45 individuals. It is important that a high return rate be achieved. My goal is to receive responses from $100 \%$ of the population.

If you have any questions, need another survey, or would prefer to submit your responses via the telephone, please contact me at 804-924-3411 (work), 804-979-9377 (home), or kds5e@virginia.edu (e-mail). Your assistance in this research project will be greatly appreciated. I look forward to hearing from you.

Sincerely,

Kathryn D. Soule

Research Associate

NOTE: If your completed survey has crossed this letter in the mail, thank you for responding! 
February 16, 1998

Dear,

On behalf of myself and the Center for the Study of Higher Education, I would like to take this opportunity to thank you for completing the survey for Student Services for Adult Undergraduate Students.

Your willingness to assist and support higher education research is evidenced by your timely response in completing the survey. I know your schedule is hectic and I appreciate the time you took to complete the survey.

Again, thank you very much.

Sincerely,

Kathryn D. Soule

Research Associate 